\title{
Biochemostratigraphy of the Upper Frasnian in the Namur-Dinant Basin, Belgium: Implications for a global Frasnian-Famennian pre-event
}

\author{
Karem Azmy ${ }^{a,}$ *, Edouard Poty ${ }^{b}$, Bernard Mottequin ${ }^{b}$ \\ ${ }^{a}$ Department of Earth Sciences, Memorial University of Newfoundland, St. John's, NL, A1B 3X5, Canada \\ b Département de géologie, Unité de paléontologie animale et humaine, Université de Liège, Allée du 6 Août, Bâtiment B 18, B-4000 Liège-1, Belgique
}

\section{a r t i c l e i n f o}

\section{Article history:}

Received 4 April 2011

Received in revised form 26 September 2011

Accepted 22 October 2011

Available online 29 October 2011

\section{Keywords:}

Chemostratigraphy

Upper Frasnian

Namur-Dinant Basin

Belgium

\begin{abstract}
a b s t r a c t
The Upper Frasnian sequence of the Namur-Dinant Basin in southern Belgium consists of mixed siliclasticcarbonate succession of a ramp setting, where the sequence spans the rhenana-linguiformis conodont zones. Earlier studies investigated the chemostratigraphic variations during the Frasnian-Famennian event, but little has been yet known about the nature of the counterpart variations that immediately preceded that time interval. Despite the scarcity of well-preserved brachiopods, sixty-one calcitic shells were collected mainly from beds of the Neuville and Les Valisettes formations (Lower and Upper rhenana zones), to investigate biochemostratigraphic profiles of oxygen-, carbon-isotope and rare earth element (REE) variations of the time interval immediately before the Frasnian-Famennian boundary. The $\delta \stackrel{18}{O}$ and $\delta \stackrel{13}{\mathrm{C}}$ values of the well-preserved shells range from -9.5 to $-5.6 \%$ VPDB $(-7.7 \pm 1.1, \mathrm{n}=33)$ and from -1.8 to $3.8 \%$ VPDB $(1.1 \pm 1.7, \mathrm{n}=33)$, respectively, which are within the documented global values. The C- and O-isotope profiles exhibit parallel shifts, particularly at the top of the Neuville Formation (top of the Lower rhenana Zone), which are associated with a sea-level rise and shrinkage in the brachiopod community. Also, the $\mathrm{Th} / \mathrm{U}(0.9 \pm 0.6, \mathrm{n}=16)$ and $\mathrm{Ce} / \mathrm{Ce}^{*}(2.2 \pm 0.5, \mathrm{n}=16)$ ratios suggest deposition under reducing conditions consistent with sea transgression.
\end{abstract}

(C) 2011 Elsevier B.V. All rights reserved.

\section{Introduction}

Biogenic allochems (e.g., brachiopods and conodonts) and some of the unaltered whole rock have been used as proxies for the evolution of original seawater chemistry during the Earth's geologic history. Geochemical studies have proven that well-preserved lowmagnesium calcite (LMC) brachiopod shells retain their primary stable isotope and trace element signatures that can be reliably utilized to study the paleoenvironmental conditions (climate and oceanography) and construct high-resolution correlations of sequences from different depositional settings (e.g. Veizer et al., 1999; Brand et al., 2004, Came et al., 2007; Brand et al., 2011). This makes the preserved brachiopod shells of the Upper Frasnian marine carbonates in the Namur-Dinant Basin (southern Belgium) a potential material for obtaining primary geochemical signatures to investigate the variations in the paleoenvironmental conditions at high resolution particularly during the time interval immediately before the global Frasnian-Famennian extinction event (Kellwasser event). Despite

\footnotetext{
* Corresponding author. Tel.: +1 709864 2589; fax: +1 7098642589.

E-mail addresses: kazmy@mun.ca (K. Azmy), E.poty@ulg.ac.be (E. Poty), bmottequin@ulg.ac.be (B. Mottequin).
}

the common occurrence of brachiopods in the investigated sequences, the well-preserved shells that can be used for geochemical studies are still rare (e.g., Azmy et al., 2009a).

The main objectives of the current study are:

(1) to investigate the primary biochemostratigraphic variations (O- and C-isotopes and REE) in the Upper Frasnian sequence (rhenana Zone) in the Namur-Dinant Basin, and

(2) to better understand the nature of the paleoenvironmental variations immediately before the Frasnian-Famennian boundary in the Namur-Dinant Basin and examine their global extension.

\section{Study area and geologic settings}

In southern Belgium, the Upper Frasnian succession (rhenana-linguiformis conodont zones) crops out extensively across the Namur Parautochtonous and in the Ardenne Autochtonous (Dinant Synclinorium, Philippeville Anticlinorium, Vesdre Nappe, Fig. 1). These major Variscan structural units constituted the Namur-Dinant Basin, which developed along the south-eastern margin of Laurussia during Devonian. In the course of the Frasnian, the facies succession reflected a ramp setting with a mixed siliclastic-carbonate sedimentation (Fig. 2) and several breaks of slope as well as the development of 


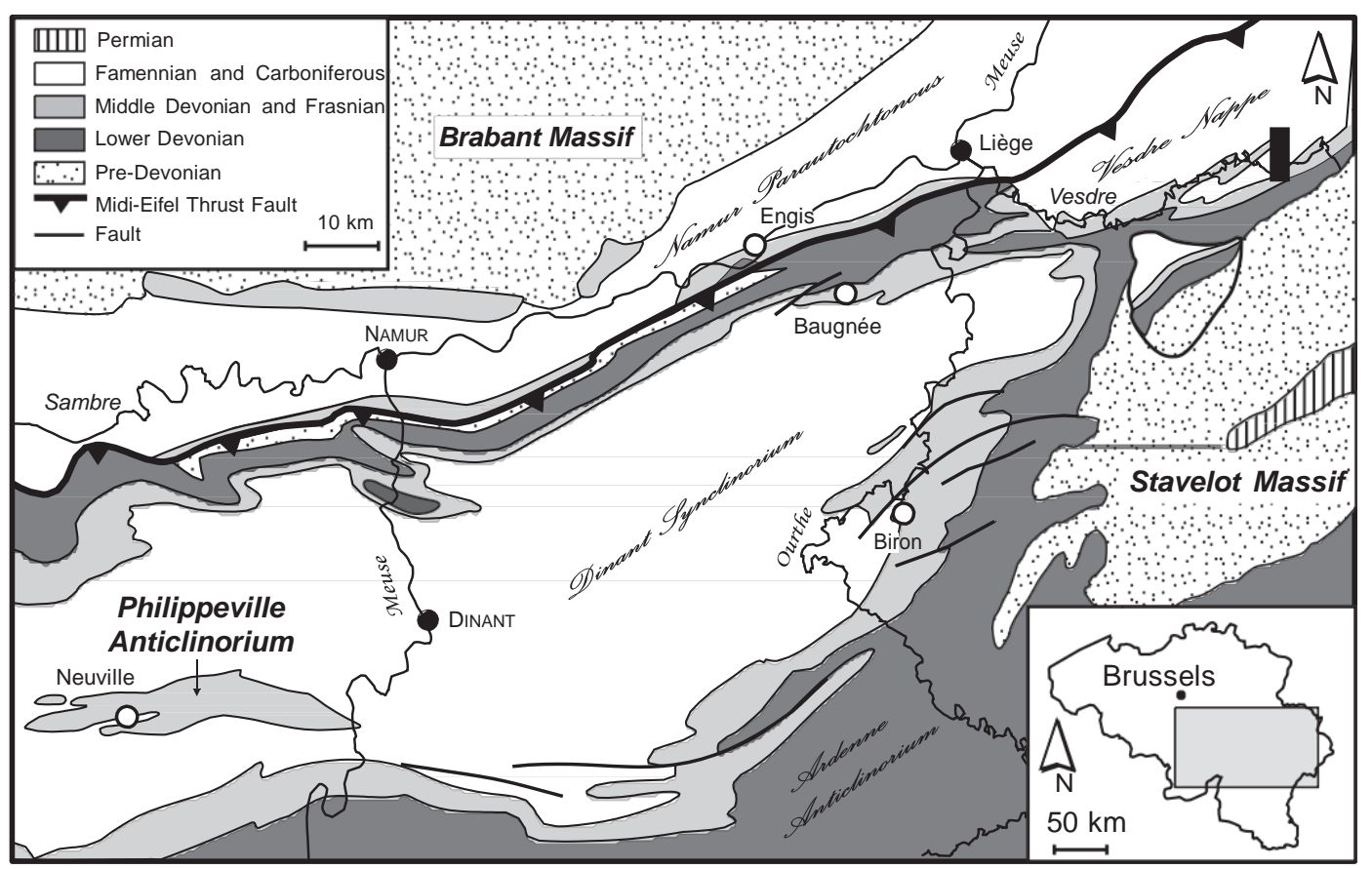

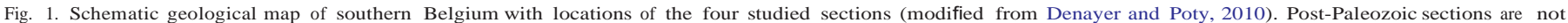
represented.

carbonate buildups in its distal part (southern flank of the Dinant Synclinorium) (e.g., Lecompte 1960, 1970; Tsien, 1975; Boulvain et al., 2004). The brachiopod shells of the current investigation were collected from four sections located in different parts of the basin and recovered from the Neuville, Les Valisettes and Aisemont formations. Brachiopod faunas from these lithostratigraphic units were recently studied by Mottequin (2005, 2008a,b,c).

The Neuville Formation (Lower rhenana Zone, Figs. 2 and 3a) consists of nodular limestone with intercalations of shales in the Philippeville Anticlinorium where its thickness is always low $(15-25 \mathrm{~m})$. On the southern flank of the Dinant Synclinorium, the shales with limestone nodules predominate and the formation attains up to $110 \mathrm{~m}$ in thickness (Coen, 1977) but the latter lithofacies decreases eastward. The reddish carbonate mud mounds (30 to $80 \mathrm{~m}$ thick), which developed within the formation and were earlier attributed to the former stratigraphic subdivision 'F2j' (Maillieux and
Demanet 1929), are now assigned to the Petit-Mont Member (Boulvain et al., 1999a; Boulvain et al., 2004).

The Les Valisettes Formation (spanning the top of the Lower rhenana Zone and Upper rhenana Zone, Figs. 2 and 3b), about $90 \mathrm{~m}$ thick in the Philippeville Anticlinorium, is rich in shales. Greenish to reddish nodular limestones and shales are locally developed (Boulvain et al., 1999b). It occurs also on the south-eastern border of the Dinant Synclinorium, between the Neuville and Barvaux formations, where its thickness is considerably reduced.

The Aisemont Formation (about 20-35 m; Lower to basal part of the Upper rhenana Zone, Figs. 2 and 3c-d) comprises limestones and argillaceous limestones in its lower and upper parts (lower and upper members); the middle part (middle member) consists of shales and nodular shales (Lacroix, 1999). Both limestone horizons are known in the Belgian literature as the first and second 'biostromes with Phillipsastrea' of Coen-Aubert and Lacroix (1979) but the 'second biostrome' is almost

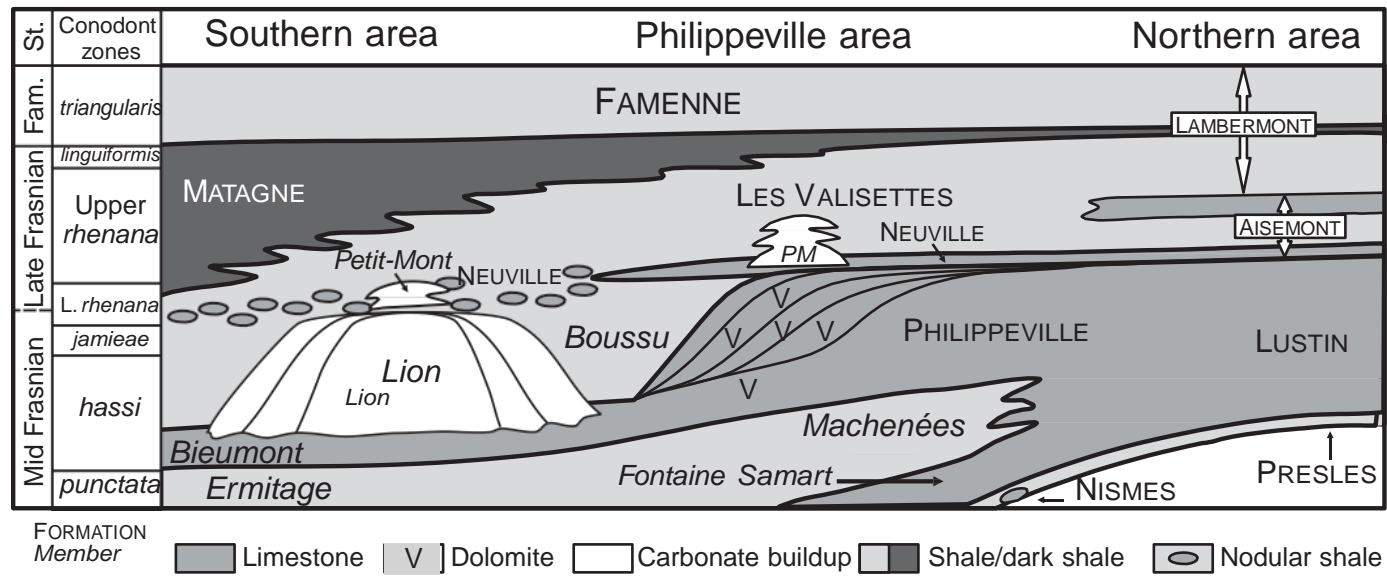

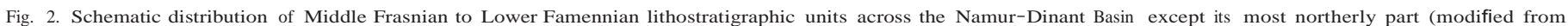

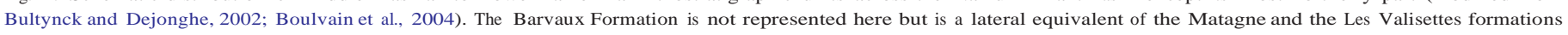
and of the lower part of the Lambermont Formation. Abbreviations: Fam., Famennian; PM, Petit-Mont Member; St., stages. 
a
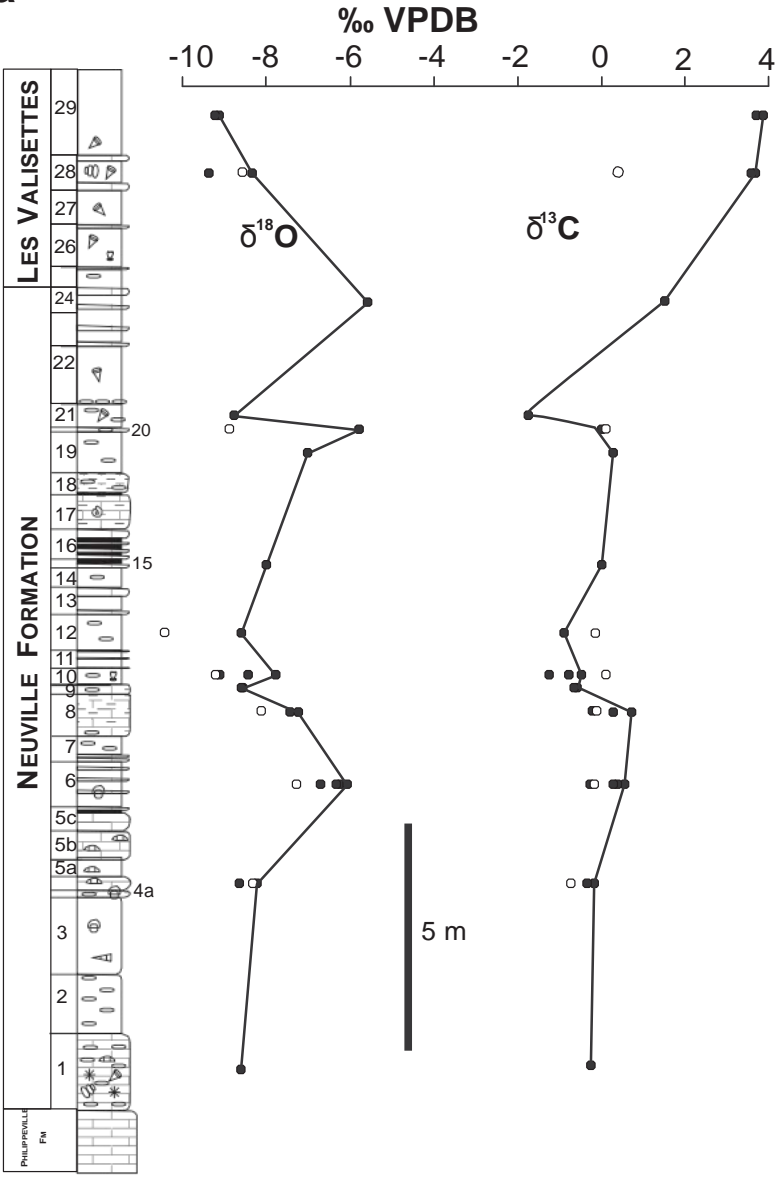

C

\%о VPDB

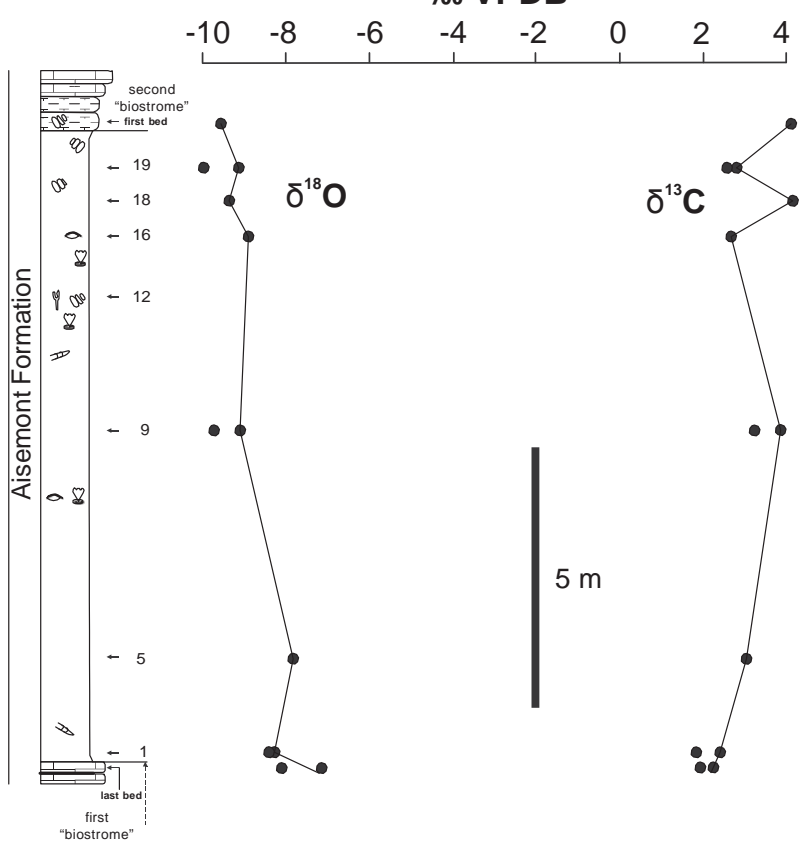

b

\%० VPDB

$\begin{array}{llllllll}-10 & -8 & -6 & -4 & -2 & 0 & 2 & 4\end{array}$

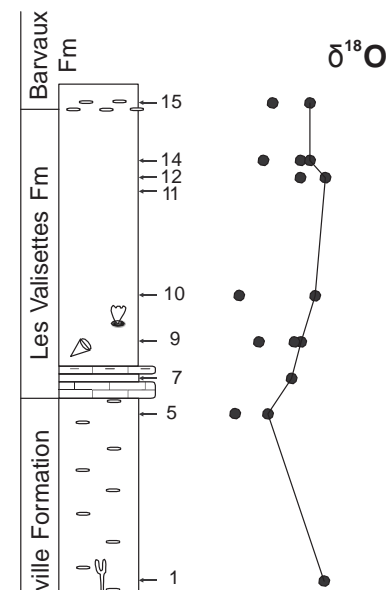

$5 \mathrm{~m}$

$\delta^{13} \mathrm{C}$

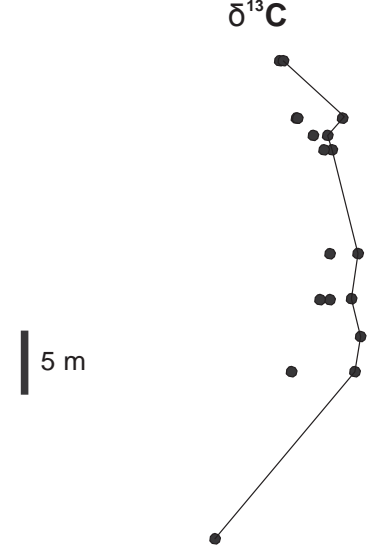

-

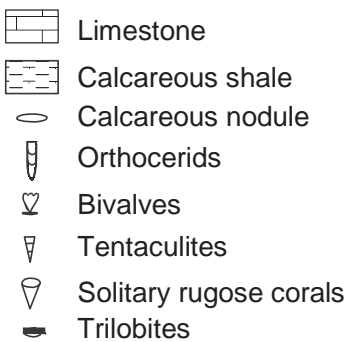

A- Argillaceous limestone

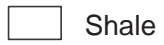

(b) Goniatites

000 Gastropods

๑ Bellerophontids

y Bryozoans

$₫$ Massive rugose corals

* Crinoids

d

\begin{tabular}{|c|c|c|c|c|c|c|c|}
\hline $\begin{array}{l}\text { Intermediate shales } \\
\text { (thickness: } 22.6 \mathrm{~m} \text { ) }\end{array}$ & & & $\%$ & 'DE & & & \\
\hline-10 & -8 & -6 & -4 & -2 & 0 & 2 & 4 \\
\hline
\end{tabular}

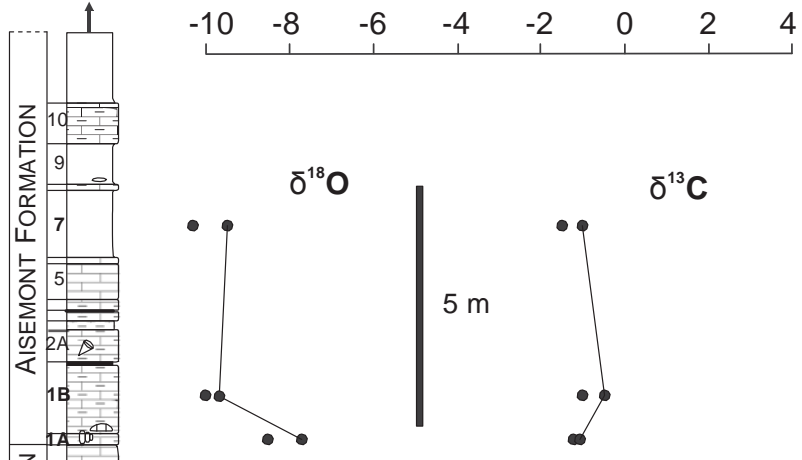

Fig. 3. Plot of the detailed $\delta^{18} \mathrm{O}$ and $\delta^{13} \mathrm{C}$ profiles of the studied sections at (a) Neuville railway station, (b) Biron, (c) La Mallieue, and (d) Baugnée. Solid circles refer to preserved shells and open circles to matrix.

devoid of biostromal units (Poty and Chevalier, 2007; Denayer and Poty, 2010). The shales of the middle member are correlated with the Lower Kellwasser Horizon (Bultynck et al., 1998).
The Neuville railway section $\left(50^{\circ} 19^{\prime} 56.06^{\prime \prime} \mathrm{N} ; 4^{\circ} 29^{\prime} 49.95^{\prime \prime} \mathrm{E}\right.$, Fig. 3a) is located south-west of the village of Neuville (Fig. 1) in a trench dug for the Couvin-Charleroi railway (e.g., Godefroid and Helsen, 1998; 
Bultynck et al., 1998; Boulvain et al., 1999a, b; Mottequin, 2005), and is part of the Philippeville Anticlinorium. It exposes an almost continuous section ranging from the top of the Philippeville Formation (hassi s.l. to lower part of the lower rhenana Zone) to the Famenne Formation (triangularis Zone).

The Biron section $\left(50^{\circ} 19^{\prime} 03.55^{\prime \prime} \mathrm{N} ; 5^{\circ} 28^{\prime} 37.59^{\prime \prime} \mathrm{E}\right.$, Fig. 3b) is located along the south-western side of the forest track linking the village to the disused halt of Biron (Coen, 1999; Mottequin, 2005) on the south-eastern margin of the Dinant Synclinorium (Fig. 1). It exposes a continuous section ranging from the top of the Neuville Formation, the Les Valisettes Formation and the base of the Barvaux Formation.

The La Mallieue section in Engis $\left(50^{\circ} 34^{\prime} 22.69^{\prime \prime} \mathrm{N}\right.$; $5^{\circ} 22^{\prime} 53.24^{\prime \prime} \mathrm{E}$, Fig. 3c) is located along the north-western side of the road from Engis to Amay in Engis (Fig. 1, Coen-Aubert and Lacroix, 1979; Mottequin, 2005; Poty and Chevalier, 2007; Denayer and Poty, 2010) and exposes the top of the Lustin Formation and almost the entire Aisemont Formation.

The Baugnée section $\left(50^{\circ} 30^{\prime} 30.22^{\prime \prime} \mathrm{N}\right.$; $\left.5^{\circ} 28^{\prime} 34.39^{\prime \prime} \mathrm{E}\right)$ (Fig. 3d) is located along the road from Nandrin to Esneux (Fig. 1, northern flank of the Dinant Synclinorium), north-west of the Tavier stream (Mottequin, 2005; Poty and Chevalier, 2007; Denayer and Poty, 2010) and offers a good opportunity to study the upper part of the Lustin Formation, the Aisemont Formation and the lower part of the Famenne Formation, but only the brachiopods from the lower carbonate member of the Aisemont Formation were investigated herein.

\section{Methods}

Despite their great abundance, well-preserved brachiopods, which may retain their primary geochemical signatures, are not common in the Upper Frasnian interval outcrops in the NamurDinant Basin of Belgium. However, 70 samples (60 brachiopod shells and 10 matrix) were collected at high-resolution (narrow sampling interval at times as small as $10 \mathrm{~cm}$ ) from beds spanning the Upper Frasnian in the Namur-Dinant Basin (Fig. 2). The samples were collected from the four sections briefly described earlier (Fig. 3a-d, Appendix 1).

Samples were cut into slabs and smashed under a binocular microscope to separate the brachiopod shells from the enclosing whole rock matrix. The brachiopod shell consists, in most cases, of three layers: a) the outermost (periostracum), which is organic and decomposes during fossilization, b) the primary layer is granular, few-micron thick calcite and always altered, and c) the secondary layer is prismatic LMC that, in many cases, resists diagenetic alterations during burial history and retains the original chemical signal of seawater (cf. Al-Aasm and Veizer, 1982; Azmy et al., 1998; Veizer et al., 1999). The secondary LMC layers of the brachiopod shells usually spalled off the matrix, although occasionally traces of the primary layer needed to be removed by a dental pick, and the shell fragments of the secondary layer were picked by forceps and cleaned in an ultrasonic bath. A shell fragment was randomly selected from each sample, coated with gold, and examined for the preservation of ultrastructure using a scanning electron microscope (SEM). The rest of each sample was powdered for chemical analyses.

About $200 \mu \mathrm{g}$ of powder of each sample was reacted in an inert atmosphere with ultrapure concentrated (100\%) orthophosphoric acid at $50{ }^{\circ} \mathrm{C}$ in a Thermo-Finnigan Gasbench II. The produced $\mathrm{CO}_{2}$ was automatically delivered to a Thermo-Finnigan DELTA V plus isotope ratio mass spectrometer to be measured for C- and O-isotope ratios. Uncertainties of better than $0.1 \%$ o $(2 \sigma)$ for the analyses were determined by repeated measurements of NBS-19 $\left(\delta^{18} \mathrm{O}=-2.20 \%\right.$ and $\delta^{13} \mathrm{C}=+1.95 \%$ vs. VPDB) and L-SVECS $\left(\delta^{18} \mathrm{O}=-26.64 \%\right.$ and $\delta^{13} \mathrm{C}=-46.48 \%$ vs. VPDB $)$ as well as internal standards.
For elemental analyses, a subset of sample powder was digested in $0.075 \mathrm{M}$ pure $\mathrm{HNO}_{3}$ and analyzed for major (e.g., Ca, $\mathrm{Mg}$ ), minor (e.g., $\mathrm{Sr}, \mathrm{Mn}, \mathrm{Fe}$ ), and REE (Coleman et al. 1989) using a HP 4500plus ICPMS at Memorial University of Newfoundland. The relative uncertainties of these measurements are better than 3\%. Normalization of REE concentrations is based on PAAS values (Post-Archean Australian Shale, McLennan, 1989), and $\mathrm{Ce}_{\mathrm{SN}}\left[(\mathrm{Ce} / \mathrm{Ce})_{\mathrm{SN}}=\mathrm{Ce}_{\mathrm{SN}} /\left(0.5 \mathrm{La}_{\mathrm{SN}}+0.5 \mathrm{Pr}_{\mathrm{SN}}\right)\right]$ and $\left.\mathrm{La}_{\mathrm{SN}}\left[\left(\mathrm{Pr} / \mathrm{Pr}^{*}\right)_{\mathrm{SN}}=\operatorname{Pr}_{\mathrm{SN}} / 0.5 \mathrm{Ce}_{\mathrm{SN}}+0.5 \mathrm{Nd}_{\mathrm{SN}}\right)\right]$ anomalies were calculated with the equations of Bau and Dulski (1996). All geochemical results are listed in Appendix 1.

\section{Results}

Evaluation of the petrographic preservation of brachiopod shells is a cornerstone procedure before geochemical analyses in order to reveal hidden post-depositional diagenetic alterations in the shell ultrastructure, which might overprint the primary geochemical signatures. In the Neuville railway-station section (spanning the Neuville Formation, Fig. 3a) and the Biron section (spanning Les Valisettes Formation, Fig. 3b), the scanning electron microscope (SEM) images of the secondary layer of the sampled shells, particularly those with the most enriched $\delta^{18} \mathrm{O}$ signals, show mainly clean calcite prisms of very good ultrastructure preservation with smooth boundaries free of diagenetic dissolution features (Fig. 4a) except for few samples that show some minor alterations (Fig. 4b). On the contrary, shells with significantly poorer preservation (Fig. 4c) are more common in the samples from the La Mallieue (Engis, spanning the Aisemont Formation, Fig. 3c) and Baugnée (spanning lower Aisemont Formation, Fig. 3d) sections, which makes those shells unreliable material for the reconstruction of primary C- and O-isotope profiles.

Table 1 summarizes the statistics of the geochemical results of stable isotope and trace element compositions of the analyzed shells. The $\delta^{18} \mathrm{O}$ values and $\delta^{13} \mathrm{C}$ values of all analyzed shells from the 4 sections (Appendix 1 and Fig. 5a,b) vary from -10.3 to $-5.6 \%$ VPDB $(-8.2 \pm 1.1 \%$ 。PDB, $\mathrm{n}=60)$ and -1.8 to $4.1 \%$ 。 VPDB $(1.5 \pm 1.8 \%$ VPDB, $n=60$ ), respectively. The O- and C-isotope compositions of the shells from the Neuville and Les Valisettes formations, that were utilized to reconstruct the compiled isotope profiles, have slightly enriched $\delta^{18} \mathrm{O}(-7.7 \pm 1.1 \%$ \% VPDB, $\mathrm{n}=33)$ and $\delta^{13} \mathrm{C}(1.1 \pm 1.7 \%$ VPDB, $n=33$ ) signatures (Table 1 ) and form two distinctive clusters (Figs. $5 \mathrm{~b}$ and 6). The Neuville cluster has lower $\delta{ }^{13} \mathrm{C}$ and wider $\delta \stackrel{18}{\mathrm{O}}$ ranges of values $(-1.8$ to $1.5 \%$ VPDB and -8.7 to $-5.6 \%$ VPDB, respectively) compared to their Les Valisettes counterparts (2.3 to 3.8\%o VPDB and -9.5 to $-7.4 \%$ VPDB, respectively).

The shells $(n=16)$ have mean $\mathrm{Sr}, \mathrm{Mn}$, Th and U contents (Table 1$)$ of $1186 \pm 384 \mathrm{ppm}, \quad 151 \pm 101 \mathrm{ppm}, \quad 0.07 \pm 0.09 \mathrm{ppm}, \quad$ and $0.10 \pm$ $0.13 \mathrm{ppm}$, respectively. The matrix samples $(\mathrm{n}=10)$ are significantly depleted in $\mathrm{Sr}(125 \pm 73 \mathrm{ppm})$ but enriched in $\mathrm{Mn}$, Th and $\mathrm{U}(752 \pm$ $664 \mathrm{ppm}, 1.6 \pm 1.3 \mathrm{ppm}$, and $0.4 \pm 1.3 \mathrm{ppm}$, respectively) compared with those of the preserved shells. The total rare earth element concentrations ( $\sum$ REE, Table 1 and Appendix 1 ) are significantly more enriched in matrix (31.6 $\pm 10.9 \mathrm{ppm}, \mathrm{n}=8)$ relative to wellpreserved brachiopod shells ( $3.5 \pm 3.7 \mathrm{ppm}, \mathrm{n}=16)$.

\section{Discussion}

\subsection{Shell preservation}

Brachiopods are generally abundant in Paleozoic marine carbonates of warm shallow-water settings and the geochemistry of their shells has been extensively used as a proxy for the evolution of ancient oceans (e.g. Lowenstam, 1961; Veizer et al., 1986; Bates and Brand, 1991; Grossman et al., 1991; Wadleigh and Veizer, 1992; Wenzel and Joachimski, 1996; Azmy et al., 1998; Bruckschen et al., 1999; Mii et al., 1999; Veizer et al., 1999; Brand and Brenckle, 2001) and for highresolution stratigraphic correlations of sequences from different 

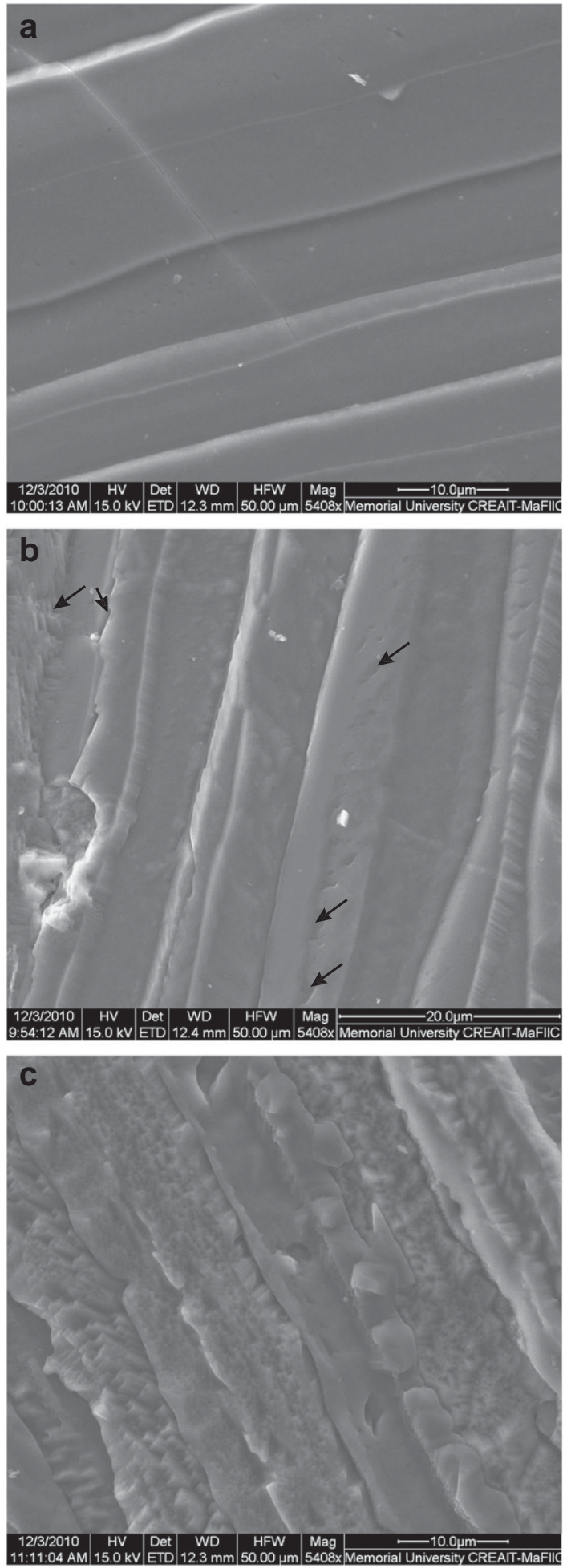

Fig. 4. Scanning Electron Microscopy photomicrographs of secondary shell layers of brachiopods from the investigated sections showing (a) very good preservation with clean calcite-prism boundaries (Sample invert-30880-0089, Neuville Formation, Appendix 1), (b) minor alteration (Sample invert-30880-0094, Neuville Formation, Appendix 1) along some of the prisms (arrows), and (c) significant alteration with distorted prisms (Sample invert-30880-00110, Aisemont Formation, Appendix 1). Geochemical attributes in Appendix 1.

sedimentary basins (e.g. Mii et al., 1999; Veizer et al., 1999; Brand and Bruckschen, 2002; Joachimski and Buggisch, 2002; Brand et al., 2004; van Geldern et al., 2006; Brand et al., 2011). Well-preserved articulated fossil brachiopod shells are among the best materials, which may retain

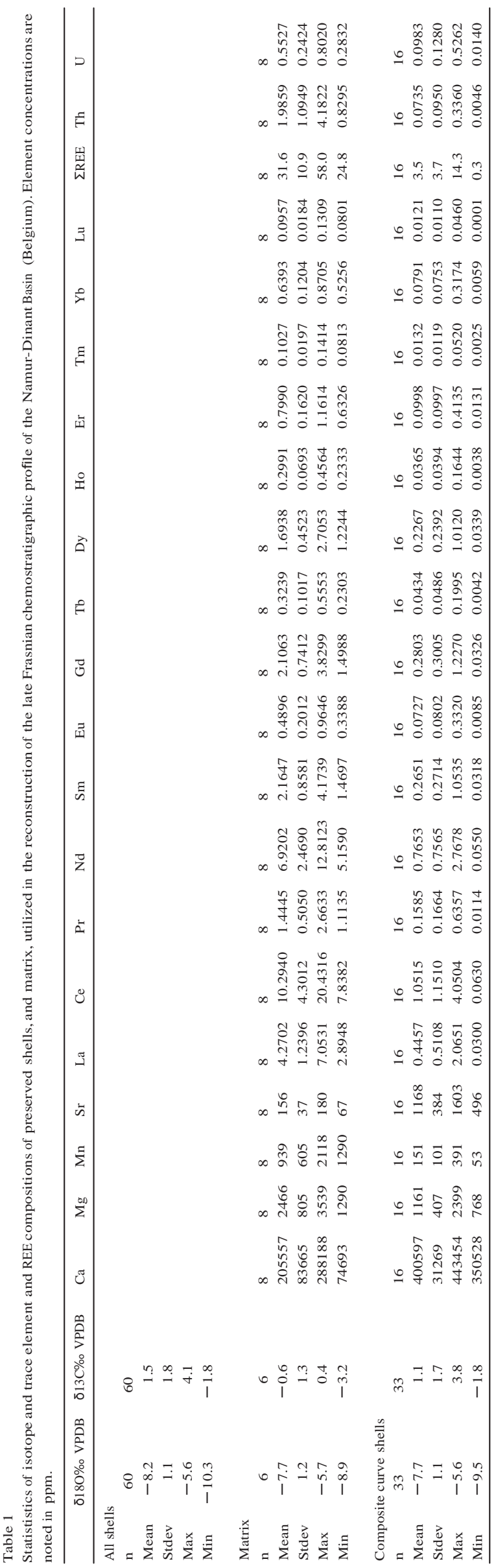


a

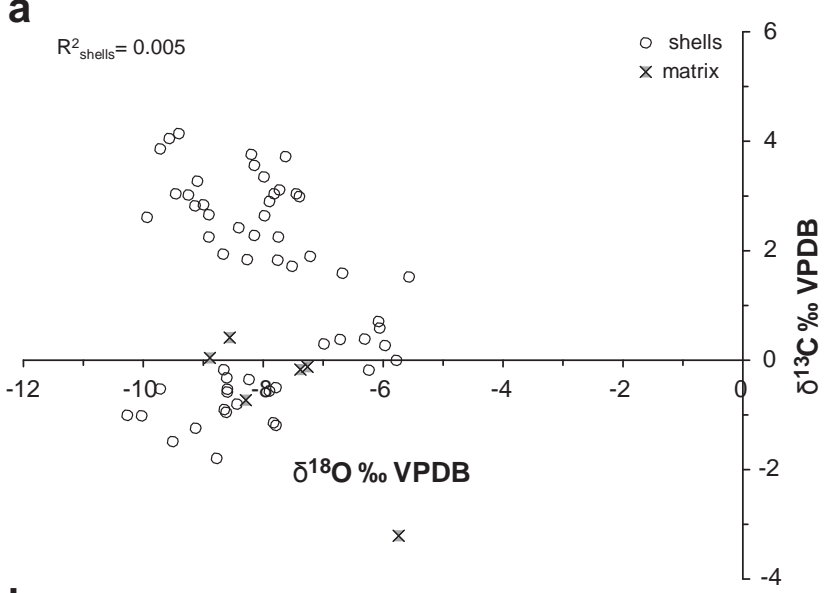

b

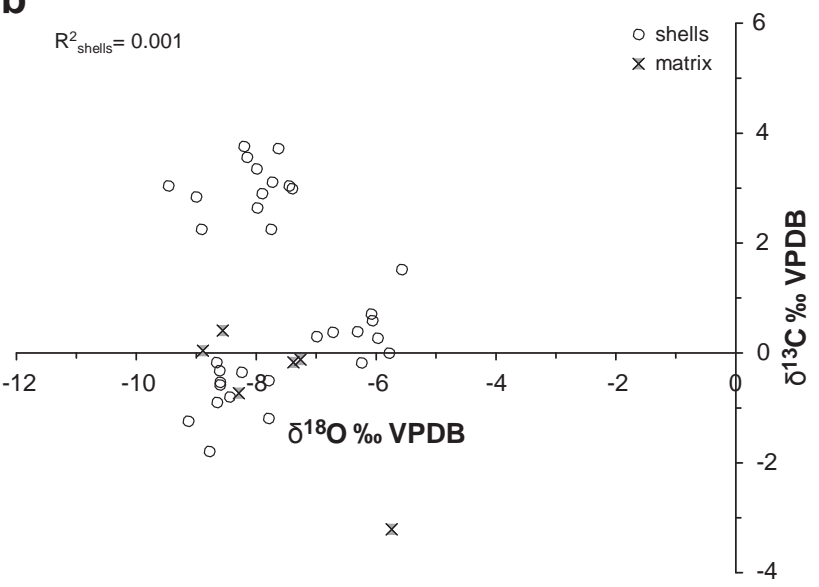

Fig. 5. Oxygen- vs. carbon-isotope values for (a) all the analyzed shells and (b) shells used for the construction of the Dinant late Frasnian composite profile (Neuville and Les Valisettes formations from the Neuville railway station and Biron sections, respectively), showing no diagenetic trend. Detail in text.

the primary geochemical signatures because they precipitate their shells, particularly the prismatic secondary layer, as LMC that at times may resist alteration except for aggressive diagenetic processes (Brand and Veizer, 1980, Brand et al., 2011). A multitechnique screening protocol has been utilized in the current study to assess the degree of preservation of each individual sample that included visual, microstructure (SEM), and stable isotope and trace element distribution (e.g. Brand et al., 2011).

The prestine preservation of the analyzed shells is reflected by their SEM images, which show stacked clean calcite prisms with no or insignificant alteration features (Fig. 4a,b) such as dissolution pits (e.g., Azmy et al. 1998; Brand et al., 2004).

The Sr, and Mn contents of the analyzed fossil shells are mainly within the range of composition documented for those of modern environment counterparts (Fig. 7a) and compositions of the matrix exhibit an outsider cluster without overlap. This suggests a high degree of preservation of primary geochemical signatures, which is also supported by the lack of diagenetic trend exhibited by $\mathrm{Mn} / \mathrm{Sr}$ vs. $\delta^{18} \mathrm{O}$ and $\delta^{13} \mathrm{C}$ (Figs. 7b,c).

The $\delta^{18} \mathrm{O}$ and $\delta^{13} \mathrm{C}$ values (Fig. 5b) show a very insignificant correlation $\left(\mathrm{R}^{2}=0.001\right)$ suggesting high degree of preservation of primary isotopic signatures. Although the isotopic composition of matrix (lime mudstone) from inside the brachiopod shells plots within the range of the preserved shells' counterpart, this still does not argue against the shell primary signatures because it is possible that the alteration of the internal lime mudstones matrix occurred at low water/ rock interaction ratio and by diagenetic fluids of precursor seawater

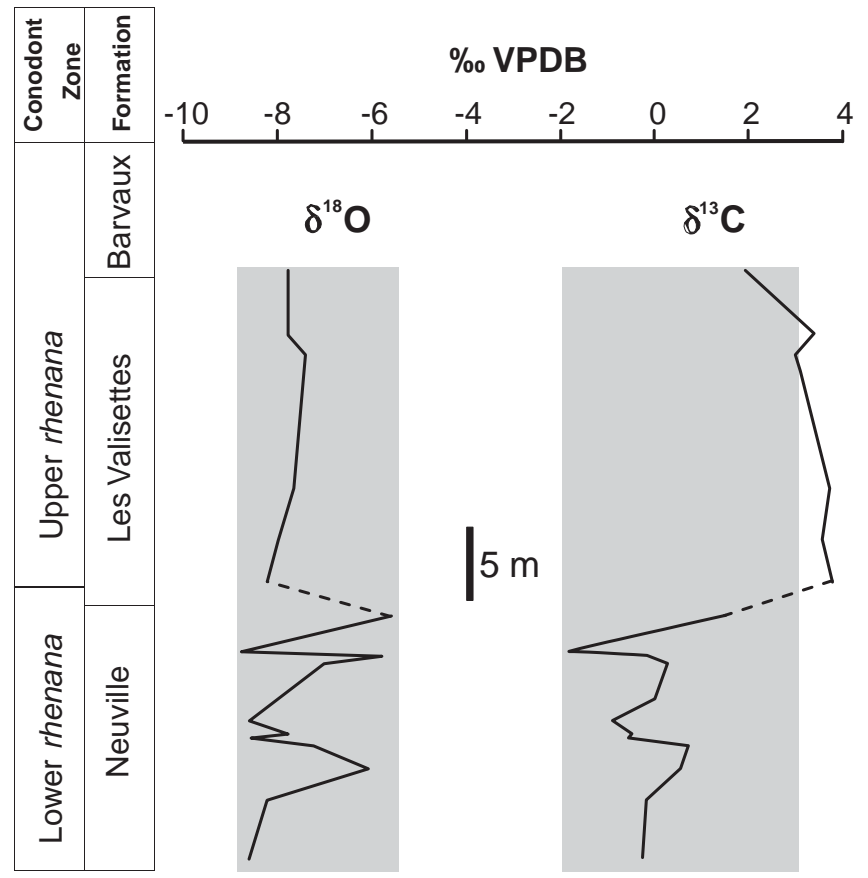

Fig. 6. Composite C-, and O-isotope profiles of the late Frasnian (rhenana Zone) across the Dinant Basin profiles. The gray shades refer to the range of documented global isotope values of counterpart sections across the approximate stratigraphic levels of the correlated rhenana Zone in Urals, Belgium, Poland and China (after Yudina et al., 2002; da Silva and Boulvain, 2008; Ma et al., 2008).

(Brand et al., 2011), which is reflected by the alteration of elemental composition of the matrix (Fig. $7 \mathrm{a}-\mathrm{c}$ ). The $\delta^{18} \mathrm{O}$ values of the studied shells are depleted relative to those of their modern ( 0\% VPDB) counterparts (Brand et al., 2003) due to the fact that the Paleozoic ocean waters were significantly depleted in ${ }^{18} \mathrm{O}$ compared with modern oceans (Veizer et al., 1999) but the fossil values are generally within the range documented for the global middle Devonian, particularly around Late Frasnian, in South China, Siberia, Europe and N. America (Joachimski and Buggisch, 1993, 1996; Veizer et al., 1999; Chen et al., 2002; Yudina et al., 2002; Joachimski et al., 2004; da Silva and Boulvain, 2008; Ma et al., 2008; Izokh et al., 2009).

The REE composition of the LMC brachiopod shells has been proven to be a possible proxy of the composition of the ambient seawater (Azmy et al., 2011). Therefore, the preservation of the fossil shells in the current study has been also examined by comparing their $\Sigma$ REE and $\mathrm{REE}_{\mathrm{SN}}$ trends with those of the matrix (diagenetic phase). The mean $\sum$ REE value of the lime mudstone matrix of internal sediments (31.6 $\pm 10.9 \mathrm{ppm}, \mathrm{n}=\mathbf{8}$, Table 1 ) is almost 10 times higher than that of the fossil shells $(3.5 \pm 3.7 \mathrm{ppm}, \mathrm{n}=16$ ), which strongly supports the high degree of preservation of shells that was reflected by their petrographic features, and major and minor elements and stable isotope signatures (e.g., Azmy et al., 2011). Also, the strong correlation of $\sum$ REE with $\delta^{18} \mathrm{O}$ of matrix (Fig. 8), relative to its insigni ficant counterpart of shells, argues for the preservation of shell primary geochemical signatures. The shale-normalized $\left(\mathrm{REE}_{\mathrm{SN}}\right)$ pattern of mean values of REE contents of matrix is also enriched by approximately one order of magnitude (Fig. 9) compared with the preserved shell counterpart. However, despite these differences in the $\Sigma$ REE values and $R_{E E}$ trends of the preserved brachiopod shells (LMC) and of the altered lime mudstones matrix (now diagenetic low-Mg calcite), they have the same patterns which may suggest that the diagenetic fluids had a precursor marine seawater, an interpretation consistent with the overlap between the C- and O-isotope compositions of matrix and those of some of preserved shells. 
a
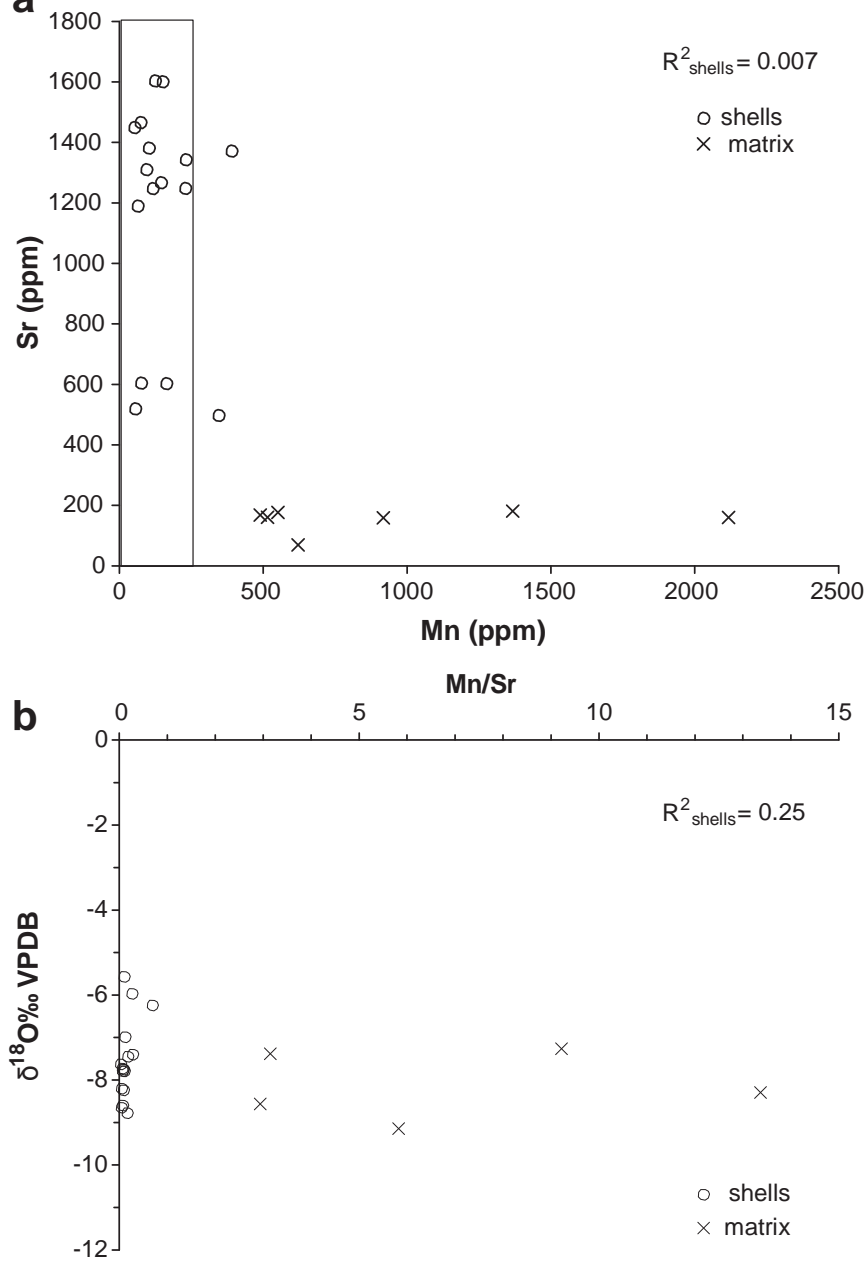

C

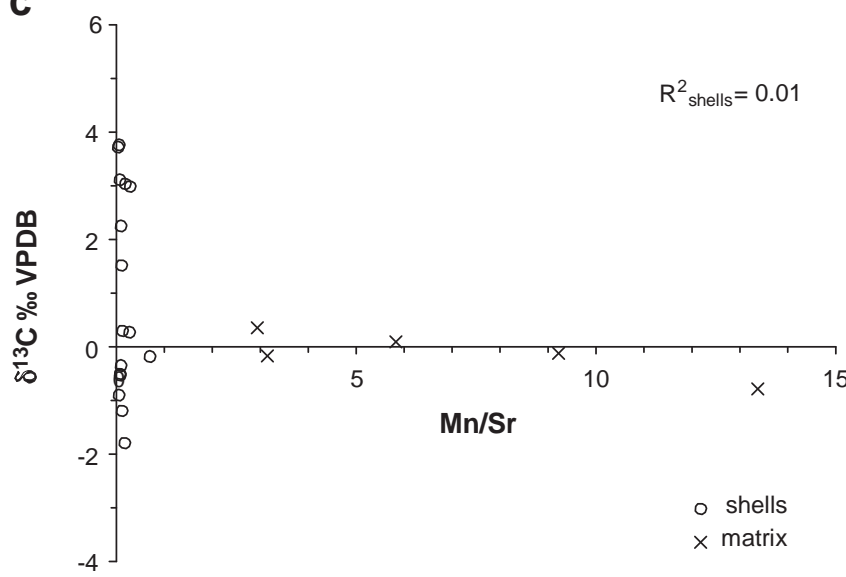

Fig. 7. Scatter diagrams of (a) Mn vs. Sr, (b) $\mathrm{Mn} / \mathrm{Sr}$ vs. $\delta \stackrel{18}{\mathrm{O}}$, and (c) $\mathrm{Mn} / \mathrm{Sr}$ vs. $\delta{ }^{13} \mathrm{C}$ for the brachiopod shells of the composite profile. The box represents the composition of modern brachiopods based on Lowenstam (1961) and Brand et al. (2003).

Based on the evaluation of the petrographic and geochemical preservation of the investigated brachiopod shells and due to common alteration in the ultrastructure of the shells collected from the Aisemont Formation (of the La Mallieue and Baugnée sections), the compiled isotope profile (Fig. 6) of the Late Frasnian in the DinantNamur Basin (Belgium) in the current investigation is only based on the signatures of the best preserved shells from the Neuville and the Les Valisettes formations from the Neuville railway-station and Biron sections, respectively.

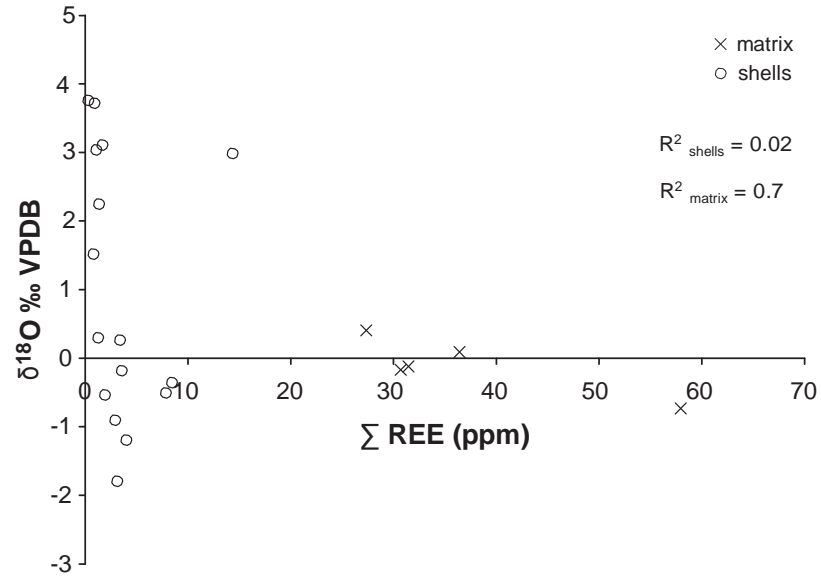

Fig. 8. Scatter diagram of $\sum$ REE vs. $\delta \stackrel{18}{O}$ showing a significant correlation by the matrix samples.

\subsection{Upper Frasnian biochemostratigraphy (Namur-Dinant Basin vs. global)}

The isotopic evolution of the seawater around the FrasnianFamennian boundary, which covers the major extinction by the Kellwasser event, has been studied globally by several authors (e.g. Joachimski and Buggisch, 1993, 1996; Veizer et al., 1999; Chen et al., 2002; Yudina et al., 2002; Joachimski et al., 2004; da Silva and Boulvain, 2008; Ma et al., 2008; Izokh et al., 2009). Although some studies utilized well preserved low-Mg calcitic brachiopod shells and phosphatic conodonts (e.g., Veizer et al., 1999; Joachimski et al., 2004), others involved frequently whole-rock samples of variable degrees of preservation, and at times low-resolution sampling (big sampling intervals), which likely masked some significant variations around the boundary. However, little attention was given to the pre-event isotopic variations during late Frasnian immediately before the major event. This requires high-resolution sampling (i.e., closely spaced intervals and having few samples from each individual horizon) in order to cover the preevent missing part of the global Devonian $\delta{ }^{18}$ and $\delta{ }^{13}$ profiles, which is maintained in this study. The $\delta^{13} \mathrm{C}$ and $\delta^{18} \mathrm{O}$ profiles of the Upper Frasnian marine carbonates of the Namur-Dinant Basin in the current investigation are re-constructed from well preserved brachiopod shells that were collected at small sampling intervals, at times as small as $10 \mathrm{~cm}$ (Fig. 3ab), and they reveal some reliable isotopic shifts, thus reflecting possible changes in climate and ocean water primary productivity.

The Upper Frasnian (rhenana Zone) of the southern margin of the Dinant Synclinorium (Belgium, Fig. 2) spans the Neuville and Les Valisettes formations and its $\delta^{1} \mathrm{O}^{\circ}$ and $\delta^{13} \mathrm{C}$ profiles exhibit covariant swings particularly in the Neuville Formation (Fig. 6) that vary from 2.5 to $3.0 \%$ VPDB and from 1.8 to $2.0 \%$ o VPDB, respectively. However, $\delta^{18} \mathrm{O}$ and $\delta^{13} \mathrm{C}$ profiles of the Les Valisettes are generally invariant and exhibit no significant variations. The general depletion in the $\delta^{13} \mathrm{C}$ values of the Neuville Formation is followed by a considerable enrichment of up to $4 \%$ VPDB (Fig. 6), thus suggesting a significant change in organic primary productivity possibly due to changes in sea-level (da Silva and Boulvain, 2008) and/or climate and surface seawater temperature, which is consistent with the correlated $\delta^{18} \mathrm{O}$ shifts shown by Oisotope profile of the same formation (Fig. 6). The isotopic shifts in the Neuville Formation $\delta^{18} \mathrm{O}$ and $\delta^{13} \mathrm{C}$ profiles seem to correlate with a transgression cycle which started around the Lower rhenana Zone after a regression during the immediately underlying jamieae Zone (Joachimski et al., 2004; Poty and Chevalier, 2007; da Silva and Boulvain, 2008). This is also consistent with a drop in the brachiopod diversity at the top of the Neuville Formation in the Neuville railway section where Bed 21 (Fig. 3a) is marked by the first appearance of a particular assemblage of thin and smooth-shelled to weakly ornamented rhynchonellids (Navalicria compacta and Flabellulirostrum sp.) and athyridides 


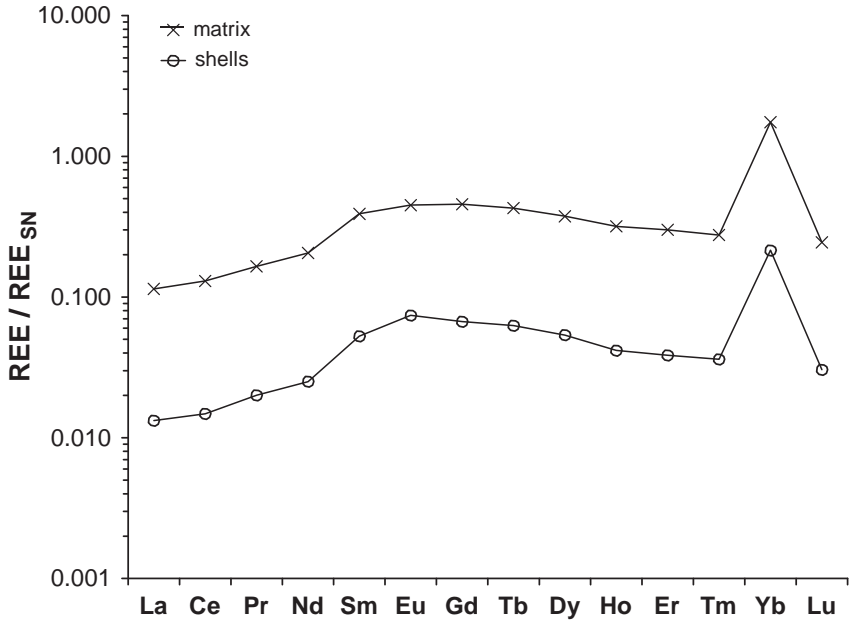

Fig. 9. Mean $\mathrm{REE}_{\mathrm{SN}}$ trends of preserved shells and matrix showing parallel patterns but significantly different values. Detail in text.

(Biernatella abunda) that were probably adapted to poor oxygenation conditions (Mottequin, 2005). In the same section, the lowest part of the overlying Les Valisettes Formation (Beds 26 to 29, Fig. 3a) is characterized by an impoverished fauna including small solitary rugose corals, bivalves (Buchiolidae) and only two brachiopod species (Cyrtospirifer sp. and an unidentified chonetidine species). The rest of the lower part of the Les Valisettes Formation, i.e. about $50 \mathrm{~m}$ of dark green shales, has almost no macrofauna (only few fragments of spiriferides were collected) and corresponds to the Lower Kellwasser Horizon (lower part of the Upper rhenana Zone) according to Bultynck et al. (1998); macrofauna only reoccur and diversify at the top of the lower part, just below the first occurrence of a thick sequence of nodular shales, limestones and nodular limestones corresponding to the middle part of the Les Valisettes Formation.

An earlier study of the global Middle to Late Devonian $\delta{ }^{18}$ profile included some data points, of suggested primary signatures, between $\sim-4.5$ and $-6.8 \%$ VPDB that clustered at a stratigraphic level around the Lower rhenana Zone but they showed poor stratigraphic resolution and no distinguishable shifts (Joachimski et al, 2004, their Fig. 2). The occurrence of this cluster around a comparable stratigraphic level (Lower rhenana Zone) to that of the shifts on the $\delta{ }^{18} \mathrm{O}$ and $\delta^{13} \mathrm{C}$ profiles (Fig. 6) of the Neuville Formation (Dinant Synclinorium, Belgium) may imply a possible global pre-Kellwasser event associated with a

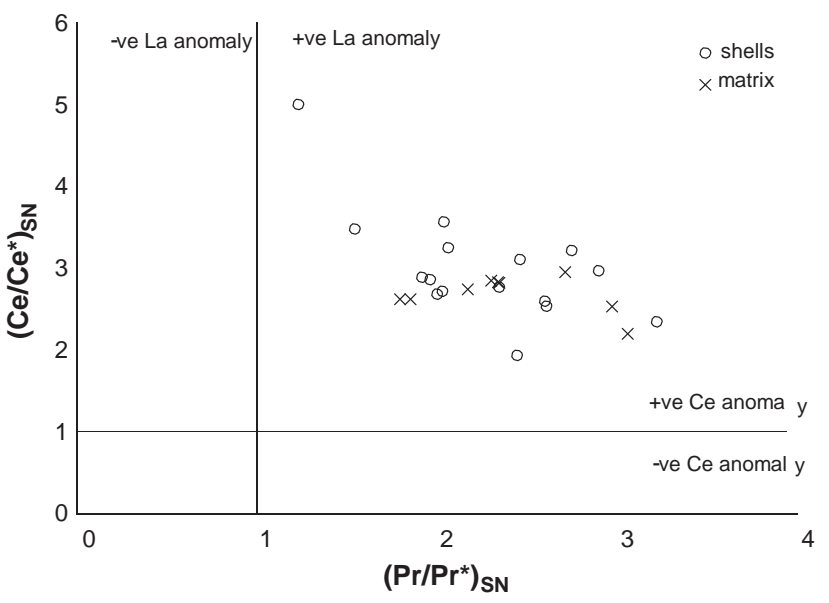

Fig. 10. Ce $\left(\mathrm{Ce} / \mathrm{Ce}_{\mathrm{SN}}\right) \mathrm{La}\left(\mathrm{Pr} / \mathrm{Pr}_{\mathrm{SN}}\right)$ anomaly evaluation of the investigated preserved fossil shell and matrix. The equations of Bau and Dulski (1996) were used to calculate the values, and to define the positive and negative Ce and La anomaly fields. Preserved shells exhibit predominantly positive Ce and La anomalies. eustatic sea-level change and paleoenvironmental variations. Although the $\delta{ }^{18} \mathrm{O}$ and $\delta^{13} \mathrm{C}$ values of carbonates of the Upper Frasnian might at times vary from basin to basin depending on the local paleoenvironmental controls such as redox conditions and local organic primary productivity in the basin (e.g., Brand et al., 2004; Immenhauser et al., 2008), those values from the investigated sections (Fig. 6, Table 1) are still within the range of the globally documented signatures.

Some REE's (e.g., U) are sensitive to redox conditions, which influence their oxidation state and selectively control their solubility in seawater and fractionation in marine carbonates (e.g., Myers and Wignall, 1987; Wignall and Twitchett, 1996; Arnaboldi and Meyers, 2007, Wignall et al., 2007, Azmy et al., 2009b). In oxidizing environment, uranium ions maintain the higher oxidation state $\left(\mathrm{U}^{+6}\right)$ and form uranyl carbonate, which is soluble in water whereas in reducing conditions, they retain the lower oxidation state $\left(\mathrm{U}^{+4}\right)$ and form the insoluble uranous fluoride which is trapped into marine carbonates (Wignall and Twitchett, 1996). On the contrary, thorium (Th) is not affected by the redox conditions of water column and occurs permanently in the insoluble $\mathrm{Th}^{+4}$ state. Accordingly, sediments of anoxic environments are richer in uranium and have lower $\mathrm{Th} / \mathrm{U}$ than those of oxic environments. Therefore, the Th/ $\mathrm{U}$ ratio has been used as a proxy of environmental redox conditions, with ratios b 2 in anoxic marine sediments, 2 to 7 in oxic sediments, and $>7$ in intensely oxidizing terrestrial environments (cf. Wignall and Twitchett, 1996). Thus, the mean Th/U ratio of the investigated shells $(0.9 \pm 0.6, n=16$, Table 1$)$ reflects an oxygendepleted environment, which is consistent with fossil evidence and the implied scenario of poor oxygenation indicated by the drop in the brachiopod population (Mottequin, 2005).

The $\mathrm{Ce}_{\mathrm{SN}}$ and $\mathrm{La}_{\mathrm{SN}}$ anomaly values have been also utilized as indicators of redox conditions (cf. Elderfield, 1988; Lee and Byrne, 1993; Webb and Kamber, 2000). The $\mathrm{Ce}_{\mathrm{SN}}$ and $\mathrm{La}_{\mathrm{SN}}$ values of the preserved brachiopods shells are positive (Fig. 10), thus suggesting oxygen-poor conditions, which is consistent with $\mathrm{Th} / \mathrm{U}$ values and the shrink in brachiopod populations associated with transgression and sea-level rise.

\section{Conclusions}

Despite the scarcity of well-preserved brachiopod shells for geochemical investigations in the Upper Frasnian marine succession (spanning the rhenana conodont Zone) in the Namur-Dinant Basin (southern Belgium), the LMC of secondary layers of the collected shells from the Neuville and Les Valisettes formations exhibits SEM images of high degree ultrastructure preservation, which is supported by their stable isotope and trace element compositions.

The investigated sections span the time interval immediately below the Frasnian-Famennian boundary (Upper Kellwasser event). The C- and O-isotope profiles of the composite succession are covariant and exhibit shifts up to 2 and 3\%, respectively. The isotope shifts are associated with $\mathrm{Th} / \mathrm{U}$ (b2) and $\mathrm{Ce} / \mathrm{Ce}^{*}(>1)$ ratios, which imply oxygen poor conditions. This is consistent with a general sea-level rise supported by drop in the brachiopod community population.

Correlations of the primary C-, and O-isotope variations of the Upper Frasnian marine carbonates from the Namur-Dinant Basin (Belgium) with counterparts from other basins on different landmasses suggest that their variations were likely caused by a global Frasnian-Famennian pre-event.

\section{Acknowledgement}

We thank the anonymous reviewers for their constructive reviews of this manuscript. Also, the efforts of Dr. Thierry Corrège (editor in chief) and Ms. Geetha Lakshmi (jounal manager) are much appreciated. Special thanks to the curators of the Royal Belgian Institute of natural Sciences (Brussels) for providing the material collected by B. Mottequin. This project was funded by research grants from Memorial University of Newfoundland, Canada (to K. Azmy). 


\begin{tabular}{|c|c|c|c|c|c|c|c|c|c|c|c|c|c|c|c|c|c|c|c|c|c|c|c|c|c|c|}
\hline $\begin{array}{l}\text { Sample id } \\
\#\end{array}$ & identification & locality & Formation & $\begin{array}{l}\text { bed or } \\
\text { sample }\end{array}$ & $\delta^{18} \mathrm{O}$ & $\delta^{18} \mathrm{C}$ & $\mathrm{Ca}$ & $\mathrm{Mg}$ & $\mathrm{Mn}$ & $\mathrm{Sr}$ & $\mathrm{La}$ & Ce & Pr & $\mathrm{Nd}$ & $\mathrm{Sm}$ & $\mathrm{Eu}$ & $\mathrm{Gd}$ & $\mathrm{Tb}$ & Dy & Но & $\mathrm{Er}$ & $\mathrm{Tm}$ & $\mathrm{Yb}$ & Lu & Th & U \\
\hline $\begin{array}{l}\text { Invert- } \\
30880- \\
0047\end{array}$ & Costatrypa sp. & $\begin{array}{l}\text { La } \\
\text { Mallieue }\end{array}$ & Aisemont & $\begin{array}{l}\text { last bed } \\
\text { of the } \\
\text { first } \\
\text { biostrome }\end{array}$ & -8.15 & 2.28 & & & & & & & & & & & & & & & & & & & & \\
\hline $\begin{array}{c}\text { Invert- } \\
30880- \\
0048\end{array}$ & Costatrypa sp. & $\begin{array}{l}\text { La } \\
\text { Mallieue }\end{array}$ & Aisemont & $\begin{array}{l}\text { last bed } \\
\text { of the } \\
\text { first } \\
\text { biostrome }\end{array}$ & -7.22 & 1.90 & & & & & & & & & & & & & & & & & & & & \\
\hline $\begin{array}{c}\text { Invert- } \\
30880- \\
0036\end{array}$ & $\begin{array}{l}\text { C. } \\
\text { condrusorum }\end{array}$ & $\begin{array}{l}\text { La } \\
\text { Mallieue }\end{array}$ & Aisemont & sample 1 & -8.27 & 1.84 & & & & & & & & & & & & & & & & & & & & \\
\hline $\begin{array}{l}\text { Invert- } \\
30880- \\
0037\end{array}$ & $\begin{array}{l}\text { C. } \\
\text { condrusorum }\end{array}$ & $\begin{array}{l}\text { La } \\
\text { Mallieue }\end{array}$ & Aisemont & sample 1 & -8.41 & 2.42 & & & & & & & & & & & & & & & & & & & & \\
\hline $\begin{array}{l}\text { Invert- } \\
30880- \\
0044\end{array}$ & $\begin{array}{l}\text { C. } \\
\text { condrusorum }\end{array}$ & $\begin{array}{l}\text { La } \\
\text { Mallieue }\end{array}$ & Aisemont & sample 5 & -7.82 & 3.04 & & & & & & & & & & & & & & & & & & & & \\
\hline $\begin{array}{c}\text { Invert- } \\
30880- \\
0039\end{array}$ & $\begin{array}{l}\text { C. } \\
\text { condrusorum }\end{array}$ & $\begin{array}{l}\text { La } \\
\text { Mallieue }\end{array}$ & Aisemont & sample 9 & -9.72 & 3.86 & & & & & & & & & & & & & & & & & & & & \\
\hline $\begin{array}{l}\text { Invert- } \\
30880- \\
0040\end{array}$ & $\begin{array}{l}\text { C. } \\
\text { condrusorum }\end{array}$ & $\begin{array}{l}\text { La } \\
\text { Mallieue }\end{array}$ & Aisemont & sample 9 & -9.10 & 3.27 & & & & & & & & & & & & & & & & & & & & \\
\hline $\begin{array}{c}\text { Invert- } \\
30880- \\
0046\end{array}$ & Productella sp. & $\begin{array}{l}\text { La } \\
\text { Mallieue }\end{array}$ & Aisemont & sample 16 & -8.91 & 2.66 & & & & & & & & & & & & & & & & & & & & \\
\hline $\begin{array}{l}\text { Invert- } \\
30880- \\
0043\end{array}$ & $\begin{array}{l}\text { C. } \\
\text { condrusorum }\end{array}$ & $\begin{array}{l}\text { La } \\
\text { Mallieue }\end{array}$ & Aisemont & sample 18 & -9.41 & 4.14 & & & & & & & & & & & & & & & & & & & & \\
\hline $\begin{array}{l}\text { Invert- } \\
30880- \\
0041\end{array}$ & $\begin{array}{l}\text { C. } \\
\text { condrusorum }\end{array}$ & $\begin{array}{l}\text { La } \\
\text { Mallieue }\end{array}$ & Aisemont & sample 19 & -9.14 & 2.82 & & & & & & & & & & & & & & & & & & & & \\
\hline $\begin{array}{l}\text { Invert- } \\
30880- \\
0042\end{array}$ & $\begin{array}{l}\text { C. } \\
\text { condrusorum }\end{array}$ & $\begin{array}{l}\text { La } \\
\text { Mallieue }\end{array}$ & Aisemont & sample 19 & -9.94 & 2.61 & & & & & & & & & & & & & & & & & & & & \\
\hline $\begin{array}{c}\text { Invert- } \\
30880- \\
0035\end{array}$ & Cyrtospirifer sp. & $\begin{array}{l}\text { La } \\
\text { Mallieue }\end{array}$ & Aisemont & $\begin{array}{l}\text { first bed of } \\
\text { the } \\
\text { second } \\
\text { biostrome }\end{array}$ & -9.57 & 4.05 & & & & & & & & & & & & & & & & & & & & \\
\hline $\begin{array}{c}\text { Invert- } \\
30880- \\
0058\end{array}$ & $\begin{array}{l}\text { C. } \\
\text { condrusorum }\end{array}$ & Biron & Barvaux & sample 15 & -7.76 & 1.83 & & & & & & & & & & & & & & & & & & & & \\
\hline $\begin{array}{l}\text { Invert- } \\
30880- \\
0059\end{array}$ & $\begin{array}{l}\text { C. } \\
\text { condrusorum }\end{array}$ & Biron & Barvaux & sample 15 & -8.67 & 1.94 & & & & & & & & & & & & & & & & & & & & \\
\hline $\begin{array}{c}\text { Invert- } \\
30880- \\
0055\end{array}$ & $\begin{array}{l}\text { C. } \\
\text { condrusorum }\end{array}$ & Biron & $\begin{array}{l}\text { Les } \\
\text { Valisettes }\end{array}$ & sample 14 & -7.75 & 2.25 & 384062 & 1117 & 117 & 1247 & 0.140 & 0.291 & 0.058 & 0.257 & 0.126 & 0.037 & 0.149 & 0.023 & 0.141 & 0.024 & 0.053 & 0.008 & 0.031 & 0.004 & 0.055 & 0.038 \\
\hline $\begin{array}{c}\text { Invert- } \\
30880- \\
0056\end{array}$ & $\begin{array}{l}\text { C. } \\
\text { condrusorum }\end{array}$ & Biron & $\begin{array}{l}\text { Les } \\
\text { Valisettes }\end{array}$ & sample 14 & -7.99 & 3.35 & & & & & & & & & & & & & & & & & & & & \\
\hline
\end{tabular}




\begin{tabular}{|c|c|c|c|c|c|c|c|c|c|c|c|c|c|c|c|c|c|c|c|c|c|c|c|c|c|c|}
\hline $\begin{array}{l}\text { Sample id } \\
\#\end{array}$ & identification & locality & Formation & $\begin{array}{l}\text { bed or } \\
\text { sample }\end{array}$ & $\delta^{18} \mathrm{O}$ & $\delta^{18} \mathrm{C}$ & $\mathrm{Ca}$ & $\mathrm{Mg}$ & $\mathrm{Mn}$ & $\mathrm{Sr}$ & $\mathrm{La}$ & $\mathrm{Ce}$ & $\operatorname{Pr}$ & $\mathrm{Nd}$ & $\mathrm{Sm}$ & $\mathrm{Eu}$ & Gd & $\mathrm{Tb}$ & Dy & Но & Er & $\mathrm{Tm}$ & $\mathrm{Yb}$ & Lu & Th & $\mathrm{U}$ \\
\hline $\begin{array}{l}\text { Invert- } \\
30880- \\
0057\end{array}$ & $\begin{array}{l}\text { C. } \\
\text { condrusorum }\end{array}$ & Biron & $\begin{array}{l}\text { Les } \\
\text { Valisettes }\end{array}$ & sample 14 & -8.91 & 2.25 & & & & & & & & & & & & & & & & & & & & \\
\hline $\begin{array}{l}\text { Invert- } \\
30880- \\
0053\end{array}$ & Cyrtospirifer sp. & Biron & $\begin{array}{l}\text { Les } \\
\text { Valisettes }\end{array}$ & sample 12 & -7.40 & 2.99 & 433118 & 2399 & 391 & 1370 & 2.065 & 4.050 & 0.636 & 2.768 & 1.053 & 0.332 & 1.227 & 0.200 & 1.012 & 0.164 & 0.414 & 0.052 & 0.317 & 0.046 & 0.034 & 0.049 \\
\hline $\begin{array}{l}\text { Invert- } \\
30880- \\
0054\end{array}$ & Cyrtospirifer sp. & Biron & $\begin{array}{l}\text { Les } \\
\text { Valisettes }\end{array}$ & sample 12 & -7.98 & 2.64 & & & & & & & & & & & & & & & & & & & & \\
\hline $\begin{array}{l}\text { Invert- } \\
30880- \\
0068\end{array}$ & $\begin{array}{l}\text { C. } \\
\text { condrusorum }\end{array}$ & Biron & $\begin{array}{l}\text { Les } \\
\text { Valisettes }\end{array}$ & sample 11 & -7.73 & 3.11 & 366651 & 1335 & 95 & 1310 & 0.231 & 0.359 & 0.069 & 0.350 & 0.125 & 0.040 & 0.174 & 0.025 & 0.148 & 0.024 & 0.053 & 0.008 & 0.054 & 0.008 & 0.075 & 0.048 \\
\hline $\begin{array}{c}\text { Invert- } \\
30880- \\
0070\end{array}$ & $\begin{array}{l}\text { C. } \\
\text { condrusorum }\end{array}$ & Biron & $\begin{array}{l}\text { Les } \\
\text { Valisettes }\end{array}$ & sample 11 & -7.90 & 2.90 & & & & & & & & & & & & & & & & & & & & \\
\hline $\begin{array}{c}\text { Invert- } \\
30880- \\
0050\end{array}$ & $\begin{array}{l}\text { C. } \\
\text { condrusorum }\end{array}$ & Biron & $\begin{array}{l}\text { Les } \\
\text { Valisettes }\end{array}$ & sample 10 & -7.63 & 3.72 & 443454 & 1164 & 53 & 1449 & 0.130 & 0.160 & 0.045 & 0.216 & 0.064 & 0.018 & 0.092 & 0.014 & 0.075 & 0.012 & 0.027 & 0.006 & 0.035 & 0.005 & 0.017 & 0.020 \\
\hline $\begin{array}{c}\text { Invert- } \\
30880- \\
0051\end{array}$ & $\begin{array}{l}\text { C. } \\
\text { condrusorum }\end{array}$ & Biron & $\begin{array}{l}\text { Les } \\
\text { Valisettes }\end{array}$ & sample 10 & -9.46 & 3.04 & & & & & & & & & & & & & & & & & & & & \\
\hline $\begin{array}{l}\text { Invert- } \\
\text { 30880- } \\
0065\end{array}$ & $\begin{array}{l}\text { C. } \\
\text { condrusorum }\end{array}$ & Biron & $\begin{array}{l}\text { Les } \\
\text { Valisettes }\end{array}$ & sample 9 & -9.00 & 2.84 & & & & & & & & & & & & & & & & & & & & \\
\hline $\begin{array}{c}\text { Invert- } \\
30880- \\
0066\end{array}$ & $\begin{array}{l}\text { C. } \\
\text { condrusorum }\end{array}$ & Biron & $\begin{array}{l}\text { Les } \\
\text { Valisettes }\end{array}$ & sample 9 & -7.45 & 3.04 & 360748 & 1415 & 229 & 1248 & 0.153 & 0.298 & 0.048 & 0.213 & 0.079 & 0.021 & 0.081 & 0.014 & 0.080 & 0.011 & 0.032 & 0.006 & 0.027 & 0.004 & 0.072 & 0.050 \\
\hline $\begin{array}{l}\text { Invert- } \\
30880- \\
0067\end{array}$ & $\begin{array}{l}\text { C. } \\
\text { condrusorum }\end{array}$ & Biron & $\begin{array}{l}\text { Les } \\
\text { Valisettes }\end{array}$ & sample 9 & -8.15 & 3.56 & & & & & & & & & & & & & & & & & & & & \\
\hline $\begin{array}{l}\text { Invert- } \\
30880- \\
0062\end{array}$ & $\begin{array}{l}\text { C. } \\
\text { condrusorum }\end{array}$ & Biron & $\begin{array}{l}\text { Les } \\
\text { Valisettes }\end{array}$ & sample 7 & -8.20 & 3.76 & 367489 & 801 & 65 & 1189 & 0.030 & 0.063 & 0.011 & 0.055 & 0.032 & 0.010 & 0.033 & 0.004 & 0.034 & 0.004 & 0.013 & 0.003 & 0.006 & 0.000 & 0.037 & 0.031 \\
\hline $\begin{array}{c}\text { Invert- } \\
30880- \\
0060\end{array}$ & C. sp. & Biron & Neuville & sample 5 & -9.57 & 2.12 & & & & & & & & & & & & & & & & & & & & \\
\hline $\begin{array}{c}\text { Invert- } \\
30880- \\
0061\end{array}$ & C. sp. & Biron & Neuville & sample 5 & -8.78 & 3.66 & & & & & & & & & & & & & & & & & & & & \\
\hline $\begin{array}{l}\text { Invert- } \\
30880- \\
0052\end{array}$ & Costatrypa sp. & Biron & Neuville & sample 1 & -7.42 & 0.24 & & & & & & & & & & & & & & & & & & & & \\
\hline $\begin{array}{l}\text { Invert- } \\
30880- \\
0071\end{array}$ & $\begin{array}{l}\text { Douvillina } \\
\text { dutertrei }\end{array}$ & $\begin{array}{l}\text { Neuville } \\
\text { railway } \\
\text { station }\end{array}$ & Neuville & bed 1 & -8.61 & -0.32 & & & & & & & & & & & & & & & & & & & & \\
\hline $\begin{array}{l}\text { Invert- } \\
30880- \\
0078\end{array}$ & C. verneuili & $\begin{array}{l}\text { Neuville } \\
\text { railway } \\
\text { station }\end{array}$ & Neuville & bed $4 a$ & -8.24 & -0.35 & 384649 & 1236 & 151 & 1601 & 0.900 & 2.959 & 0.382 & 1.865 & 0.596 & 0.153 & 0.623 & 0.092 & 0.444 & 0.070 & 0.180 & 0.022 & 0.134 & 0.021 & 0.125 & 0.179 \\
\hline $\begin{array}{l}\text { Invert- } \\
30880- \\
0079\end{array}$ & C. verneuili & $\begin{array}{l}\text { Neuville } \\
\text { railway } \\
\text { station }\end{array}$ & Neuville & bed $4 a$ & -8.66 & -0.17 & & & & & & & & & & & & & & & & & & & & \\
\hline $\begin{array}{c}\text { Invert- } \\
30880- \\
0081\end{array}$ & P. godefroidi & $\begin{array}{l}\text { Neuville } \\
\text { railway } \\
\text { station }\end{array}$ & Neuville & bed 6 & -6.72 & 0.38 & & & & & & & & & & & & & & & & & & & & \\
\hline $\begin{array}{l}\text { Invert- } \\
30000-\end{array}$ & P. godefroidi & $\begin{array}{l}\text { Neuville } \\
\text { railway }\end{array}$ & Neuville & bed 6 & -6.31 & 0.39 & & & & & & & & & & & & & & & & & & & & \\
\hline 0082 & & station & & & & & & & & & & & & & & & & & & & & & & con & d o & xt page) \\
\hline
\end{tabular}




\begin{tabular}{|c|c|c|c|c|c|c|c|c|c|c|c|c|c|c|c|c|c|c|c|c|c|c|c|c|c|c|}
\hline $\begin{array}{l}\text { Invert- } \\
30880 \\
-0083\end{array}$ & P. godefroidi & $\begin{array}{l}\text { Neuville } \\
\text { railway } \\
\text { station }\end{array}$ & Neuville & bed 6 & -6.24 & -0.18 & 392188 & 835 & 346 & 496 & 0.391 & 0.935 & 0.143 & 0.794 & 0.272 & 0.085 & 0.314 & 0.046 & 0.261 & 0.048 & 0.133 & 0.017 & 0.099 & 0.014 & 0.039 & 0.526 \\
\hline $\begin{array}{c}\text { Invert- } \\
30880- \\
0084\end{array}$ & P. godefroidi & $\begin{array}{l}\text { Neuville } \\
\text { railway } \\
\text { station }\end{array}$ & Neuville & bed 6 & -6.06 & 0.59 & & & & & & & & & & & & & & & & & & & & \\
\hline $\begin{array}{l}\text { Invert- } \\
30880- \\
0085\end{array}$ & P. godefroidi & $\begin{array}{l}\text { Neuville } \\
\text { railway } \\
\text { station }\end{array}$ & Neuville & bed 8 & -5.97 & 0.27 & 408715 & 768 & 164 & 602 & 0.487 & 0.990 & 0.147 & 0.724 & 0.240 & 0.050 & 0.230 & 0.038 & 0.206 & 0.035 & 0.103 & 0.013 & 0.094 & 0.013 & 0.025 & 0.202 \\
\hline $\begin{array}{l}\text { Invert- } \\
30880- \\
0086\end{array}$ & P. godefroidi & $\begin{array}{l}\text { Neuville } \\
\text { railway } \\
\text { station }\end{array}$ & Neuville & bed 8 & -6.08 & 0.71 & & & & & & & & & & & & & & & & & & & & \\
\hline $\begin{array}{l}\text { Invert- } \\
30880- \\
0087\end{array}$ & T. bironensis & $\begin{array}{l}\text { Neuville } \\
\text { railway } \\
\text { station }\end{array}$ & Neuville & bed 9 & -8.60 & -0.58 & & & & & & & & & & & & & & & & & & & & \\
\hline $\begin{array}{l}\text { Invert- } \\
30880- \\
0088\end{array}$ & T. bironensis & $\begin{array}{l}\text { Neuville } \\
\text { railway } \\
\text { station }\end{array}$ & Neuville & bed 9 & -8.60 & -0.53 & 418400 & 850 & 125 & 1603 & 0.182 & 0.512 & 0.091 & 0.503 & 0.157 & 0.067 & 0.151 & 0.020 & 0.115 & 0.020 & 0.046 & 0.007 & 0.040 & 0.007 & 0.015 & 0.064 \\
\hline $\begin{array}{l}\text { Invert- } \\
30880- \\
0072\end{array}$ & T. bironensis & $\begin{array}{l}\text { Neuville } \\
\text { railway } \\
\text { station }\end{array}$ & Neuville & bed 10 & -9.13 & -1.24 & & & & & & & & & & & & & & & & & & & & \\
\hline $\begin{array}{l}\text { Invert- } \\
30880- \\
0073\end{array}$ & T. bironensis & $\begin{array}{l}\text { Neuville } \\
\text { railway } \\
\text { station }\end{array}$ & Neuville & bed 10 & -7.79 & -0.50 & 350528 & 993 & 103 & 1381 & 0.979 & 2.596 & 0.363 & 1.834 & 0.587 & 0.120 & 0.509 & 0.079 & 0.364 & 0.066 & 0.187 & 0.019 & 0.124 & 0.021 & 0.267 & 0.111 \\
\hline $\begin{array}{l}\text { Invert- } \\
30880- \\
0074\end{array}$ & T. bironensis & $\begin{array}{l}\text { Neuville } \\
\text { railway } \\
\text { station }\end{array}$ & Neuville & bed 10 & -8.44 & -0.80 & & & & & & & & & & & & & & & & & & & & \\
\hline $\begin{array}{c}\text { Invert- } \\
30880- \\
0075\end{array}$ & T. bironensis & $\begin{array}{l}\text { Neuville } \\
\text { railway } \\
\text { station }\end{array}$ & Neuville & bed 12 & -8.65 & -0.90 & 377774 & 1212 & 74 & 1466 & 0.450 & 0.928 & 0.140 & 0.633 & 0.173 & 0.041 & 0.181 & 0.026 & 0.150 & 0.025 & 0.067 & 0.011 & 0.063 & 0.011 & 0.016 & 0.015 \\
\hline $\begin{array}{l}\text { Invert- } \\
30880- \\
0094\end{array}$ & T. bironensis & $\begin{array}{l}\text { Neuville } \\
\text { railway } \\
\text { station }\end{array}$ & Neuville & bed 15 & -7.79 & -1.19 & 416769 & 1557 & 145 & 1266 & 0.460 & 1.221 & 0.176 & 0.863 & 0.303 & 0.069 & 0.301 & 0.053 & 0.245 & 0.036 & 0.125 & 0.017 & 0.108 & 0.017 & 0.027 & 0.131 \\
\hline $\begin{array}{c}\text { Invert- } \\
30880- \\
10095\end{array}$ & Costatrypa sp. & $\begin{array}{l}\text { Neuville } \\
\text { railway } \\
\text { station }\end{array}$ & Neuville & bed 19 & -6.99 & 0.30 & 442087 & 992 & 76 & 604 & 0.149 & 0.374 & 0.065 & 0.314 & 0.099 & 0.023 & 0.084 & 0.011 & 0.068 & 0.006 & 0.035 & 0.006 & 0.016 & 0.006 & 0.005 & 0.014 \\
\hline $\begin{array}{l}\text { Invert- } \\
30880- \\
0096\end{array}$ & $\begin{array}{l}\text { Navalicria } \\
\text { compacta }\end{array}$ & $\begin{array}{l}\text { Neuville } \\
\text { railway } \\
\text { station }\end{array}$ & Neuville & bed 20 & -5.78 & 0.00 & & & & & & & & & & & & & & & & & & & & \\
\hline $\begin{array}{c}\text { Invert- } \\
30880- \\
0089\end{array}$ & $\begin{array}{l}\text { C. } \\
\text { condrusorum }\end{array}$ & $\begin{array}{l}\text { Neuville } \\
\text { railway } \\
\text { station }\end{array}$ & Neuville & bed 21 & -8.78 & -1.79 & 435851 & 1133 & 231 & 1343 & 0.269 & 0.799 & 0.131 & 0.701 & 0.294 & 0.089 & 0.291 & 0.044 & 0.243 & 0.033 & 0.101 & 0.012 & 0.091 & 0.011 & 0.057 & 0.081 \\
\hline $\begin{array}{l}\text { Invert- } \\
30880- \\
0102\end{array}$ & $\begin{array}{l}\text { Flabellulirostrum } \\
\text { sp. }\end{array}$ & $\begin{array}{l}\text { Neuville } \\
\text { railway } \\
\text { station }\end{array}$ & Neuville & bed 24 & -5.57 & 1.52 & 427062 & 776 & 56 & 519 & 0.115 & 0.287 & 0.031 & 0.154 & 0.039 & 0.009 & 0.046 & 0.006 & 0.042 & 0.006 & 0.030 & 0.004 & 0.025 & 0.004 & 0.009 & 0.015 \\
\hline $\begin{array}{l}\text { Invert- } \\
30880- \\
0090\end{array}$ & $\begin{array}{l}\text { C. } \\
\text { condrusorum }\end{array}$ & $\begin{array}{l}\text { Neuville } \\
\text { railway } \\
\text { station }\end{array}$ & $\begin{array}{l}\text { Les } \\
\text { Valisettes }\end{array}$ & bed 28 & -9.38 & 3.54 & & & & & & & & & & & & & & & & & & & & \\
\hline $\begin{array}{l}\text { Invert- } \\
30880- \\
0091\end{array}$ & $\begin{array}{l}\text { C. } \\
\text { condrusorum }\end{array}$ & $\begin{array}{l}\text { Neuville } \\
\text { railway } \\
\text { station }\end{array}$ & $\begin{array}{l}\text { Les } \\
\text { Valisettes }\end{array}$ & bed 28 & -8.37 & 3.67 & & & & & & & & & & & & & & & & & & & & \\
\hline $\begin{array}{l}\text { Invert- } \\
30880- \\
0092\end{array}$ & $\begin{array}{l}\text { C. } \\
\text { condrusorum }\end{array}$ & $\begin{array}{l}\text { Neuville } \\
\text { railway } \\
\text { station }\end{array}$ & $\begin{array}{l}\text { Les } \\
\text { Valisettes }\end{array}$ & bed 29 & -9.13 & 3.71 & & & & & & & & & & & & & & & & & & & & \\
\hline $\begin{array}{l}\text { Invert- } \\
30880- \\
0093\end{array}$ & $\begin{array}{l}\text { C. } \\
\text { condrusorum }\end{array}$ & $\begin{array}{l}\text { Neuville } \\
\text { railway } \\
\text { station }\end{array}$ & $\begin{array}{l}\text { Les } \\
\text { Valisettes }\end{array}$ & bed 29 & -9.20 & 3.86 & & & & & & & & & & & & & & & & & & & & \\
\hline
\end{tabular}




\begin{tabular}{|c|c|c|c|c|c|c|c|c|c|c|c|c|c|c|c|c|c|c|c|c|c|c|c|c|c|c|}
\hline $\begin{array}{l}\text { Sample id } \\
\#\end{array}$ & identification & locality & Formation & $\begin{array}{l}\text { bed or } \\
\text { sample }\end{array}$ & $\delta^{18} \mathrm{O}$ & $\delta^{18} \mathrm{C}$ & $\mathrm{Ca}$ & Mg & $\mathrm{Mn}$ & $\mathrm{Sr}$ & $\mathrm{La}$ & $\mathrm{Ce}$ & Pr & $\mathrm{Nd}$ & Sm & $\mathrm{Eu}$ & $\mathrm{Gd}$ & $\mathrm{Tb}$ & Dy & Ho & Er & $\mathrm{Tm}$ & $\mathrm{Yb}$ & Lu & Th & $\mathrm{U}$ \\
\hline $\begin{array}{c}\text { Invert- } \\
30880- \\
0109\end{array}$ & Schizophoria sp. & Baugnée & Aisemont & bed $1 \mathrm{~A}$ & -8.62 & -0.95 & & & & & & & & & & & & & & & & & & & & \\
\hline $\begin{array}{c}\text { Invert- } \\
30880- \\
0110\end{array}$ & Schizophoria sp. & Baugnée & Aisemont & bed $1 \mathrm{~A}$ & -7.83 & -1.14 & & & & & & & & & & & & & & & & & & & & \\
\hline $\begin{array}{c}\text { Invert- } \\
\text { 30880- } \\
0111\end{array}$ & T. bironensis & Baugnée & Aisemont & bed 1B & -9.72 & -0.53 & & & & & & & & & & & & & & & & & & & & \\
\hline $\begin{array}{c}\text { Invert- } \\
30880- \\
0112\end{array}$ & T. bironensis & Baugnée & Aisemont & bed 1B & -10.03 & -1.02 & & & & & & & & & & & & & & & & & & & & \\
\hline $\begin{array}{c}\text { Invert- } \\
30880- \\
0113\end{array}$ & Cyrtospirifer sp. & Baugnée & Aisemont & bed 7 & -9.51 & -1.49 & & & & & & & & & & & & & & & & & & & & \\
\hline $\begin{array}{c}\text { Invert- } \\
30880- \\
0114\end{array}$ & Cyrtospirifer sp. & Baugnée & Aisemont & bed 7 & -10.27 & -1.01 & & & & & & & & & & & & & & & & & & & & \\
\hline $1-74 \mathrm{~m}$ & matrix & $\begin{array}{l}\text { Neuville } \\
\text { railway } \\
\text { station }\end{array}$ & Neuville & bed 10 & -9.14 & 0.09 & 221297 & 2320 & 918 & 158 & 5.190 & 11.016 & 1.612 & 7.490 & 2.217 & 0.463 & 2.331 & 0.398 & 2.284 & 0.447 & 1.321 & 0.187 & 1.272 & 0.189 & 2.546 & 2.927 \\
\hline $1-75 \mathrm{~m}$ & matrix & $\begin{array}{l}\text { Neuville } \\
\text { railway } \\
\text { station }\end{array}$ & Neuville & bed 12 & -10.47 & -0.22 & & & & & & & & & & & & & & & & & & & & \\
\hline $1-76 \mathrm{~m}$ & matrix & $\begin{array}{l}\text { Neuville } \\
\text { railway } \\
\text { station }\end{array}$ & Neuville & bed 3 & -5.74 & -3.21 & & & & & & & & & & & & & & & & & & & & \\
\hline $1-79 m$ & matrix & $\begin{array}{l}\text { Neuville } \\
\text { railway } \\
\text { station }\end{array}$ & Neuville & bed $4 a$ & -8.29 & -0.73 & 288188 & 2730 & 2118 & 158 & 7.053 & 20.432 & 2.663 & 12.812 & 4.174 & 0.965 & 3.830 & 0.555 & 2.705 & 0.456 & 1.161 & 0.141 & 0.871 & 0.131 & 1.251 & 0.694 \\
\hline $1-81 \mathrm{~m}$ & matrix & $\begin{array}{l}\text { Neuville } \\
\text { railway } \\
\text { station }\end{array}$ & Neuville & bed 6 & -7.26 & -0.12 & 74693 & 1388 & 621 & 67 & 3.835 & 11.747 & 1.375 & 6.381 & 1.942 & 0.419 & 1.957 & 0.313 & 1.627 & 0.298 & 0.765 & 0.096 & 0.614 & 0.089 & 1.540 & 0.300 \\
\hline $1-85 \mathrm{~m}$ & matrix & $\begin{array}{l}\text { Neuville } \\
\text { railway } \\
\text { station }\end{array}$ & Neuville & bed 8 & -7.38 & -0.17 & 286044 & 2814 & 551 & 175 & 4.174 & 9.630 & 1.458 & 7.127 & 2.116 & 0.445 & 2.094 & 0.313 & 1.620 & 0.280 & 0.735 & 0.091 & 0.538 & 0.081 & 0.830 & 0.799 \\
\hline 1-90m & matrix & $\begin{array}{l}\text { Neuville } \\
\text { railway } \\
\text { station }\end{array}$ & $\begin{array}{l}\text { Les } \\
\text { Valisettes }\end{array}$ & bed 28 & -8.56 & 0.41 & 90055 & 1290 & 489 & 167 & 2.895 & 7.838 & 1.245 & 6.408 & 2.234 & 0.527 & 2.232 & 0.347 & 1.781 & 0.304 & 0.772 & 0.094 & 0.596 & 0.080 & 4.182 & 0.436 \\
\hline 1-95m & matrix & $\begin{array}{l}\text { Neuville } \\
\text { railway } \\
\text { station }\end{array}$ & $\begin{array}{l}\text { Les } \\
\text { Valisettes }\end{array}$ & bed 28 & & & 201712 & 3539 & 515 & 159 & 3.617 & 8.242 & 1.263 & 6.297 & 2.038 & 0.447 & 1.916 & 0.311 & 1.684 & 0.295 & 0.840 & 0.117 & 0.710 & 0.110 & 2.578 & 0.283 \\
\hline $1-97 m$ & matrix & $\begin{array}{l}\text { Neuville } \\
\text { railway } \\
\text { station }\end{array}$ & Neuville & bed 3 & -8.89 & 0.04 & & & & & & & & & & & & & & & & & & & & \\
\hline $1-102 m$ & matrix & $\begin{array}{l}\text { Neuville } \\
\text { railway } \\
\text { station }\end{array}$ & Neuville & bed 24 & & & 257580 & 2353 & 1367 & 180 & 4.609 & 8.098 & 1.146 & 5.187 & 1.470 & 0.342 & 1.529 & 0.237 & 1.224 & 0.235 & 0.669 & 0.088 & 0.537 & 0.087 & 1.426 & 0.797 \\
\hline
\end{tabular}




\section{References}

Al-Aasm, I., Veizer, J., 1982. Chemical stabilization of low-Mg calcite: an example of brachiopods. Journal of Sedimentary Petrology 52, 1101-1109.

Arnaboldi, M., Meyers, P.A., 2007. Trace element indicators of increased primary production and decreased water-column ventilation during deposition of latest Pliocene sapropels at five locations across the Mediterranean Sea. Palaeogeography, Palaeoclimatology, Palaeoecology 249, 425-443.

Azmy, K., Veizer, J., Bassett, M.G., Copper, P., 1998. Oxygen and carbon isotopic composition of Silurian brachiopods: implications for seawater isotopic composition and glaciation. Geological Society of America Bulletin 110, 1499-1512.

Azmy, K., Poty, E., Brand, U., 2009a. High-resolution isotope stratigraphy of the DevonianCarboniferous boundary in Namur-Dinant Basin, Belgium. Sedimentary Geology 216, 117-124.

Azmy, K., Sylvester, P., de Oliveira, T.F., 2009b. Oceanic redox conditions in the Late Mesoproterozoic recorded in the Upper Vazante Group carbonates of São Francisco Basin, Brazil: stable isotopes and REE evidences. Precambrian Research 168, 259-279.

Azmy, K., Brand, U., Sylvester, P., Gleeson, S., Logan, A., Bitner, M.A., 2011. Biogenic low-Mg calcite (brachiopods): proxy of seawater-REE composition, natural processes and diagenetic alteration. Chemical Geology 280, 180-190.

Bates, N.R., Brand, U., 1991. Environmental and physiological influences on isotopic and elemental compositions of brachiopod shell calcite: implications for the isotopic evolution of Paleozoic oceans. Chemical Geology: Isotope Geoscience section 94, 67-78.

Bau, M., Dulski, P., 1996. Distribution of yttrium and rare-earth elements in the Penge and Kuruman iron-formations, Transvaal Supergroup, South Africa. Precambrian Research 79, 37-55.

Boulvain, F., Coen, M., Coen-Aubert, M., 1999a. Formation de Neuville. Memoirs of the Geological Survey of Belgium 44, 74-79.

Boulvain, F., Coen, M., Coen-Aubert, M., 1999b. Formation des Valisettes. Memoirs of the Geological Survey of Belgium 44, 80-82.

Boulvain, F., Cornet, P., da Silva, A.C., Delaite, G., Demany, B., Humblet, M., Renard, M., Coen-Aubert, M., 2004. Reconstructing atoll-like mounds from the Frasnian of Belgium. Facies 50, 313-326.

Brand, U., Brenckle, P., 2001. Chemostratigraphy of the Mid-Carboniferous boundary global stratotype section and point (GSSP), Bird Spring Formation, Arrow Canyon, Nevada, USA. Paleogeography, Paleoclimatology, Paleoecology 165, 321-347.

Brand, U., Bruckschen, P., 2002. Correlation of the Askyn River section, southern Urals, Russia with the Mid-Carboniferous boundary GSSP, Bird Spring Formation, Arrow Canyon, Nevada, USA: implications for global paleoceanography. Palaeogeography, Palaeoclimatology, Palaeoecology 184, 177-193.

Brand, U., Veizer, J., 1980. Chemical diagenesis of a multicomponent carbonate system: 1. Trace elements. Journal of Sedimentary Petrology 50, 1219-1236.

Brand, U., Logan, A., Hiller, N., Richardson, J., 2003. Geochemistry of modern brachiopods: applications and implications for oceanography and paleoceanography. Chemical Geology 198, 305-334

Brand, U., Legrand-Blain, M., Streel, M., 2004. Biochemostratigraphy of the DevonianCarboniferous boundary global stratotype section and point, Griotte Formation, La Serre, Montagne Noire, France. Palaeogeography, Palaeoclimatology, Palaeoecology 205, 337-357.

Brand, U., Logan, A., Bitner, M.A., Griesshaber, E., Azmy, K., Buhl, D., 2011. What is the ideal proxy of Paleozoic seawater? The Association of Australasian Palaeontologists, Memoir 41, 9-24.

Bruckschen, P., Oesmann, S., Veizer, J., 1999. Isotope stratigraphy of the European Carboniferous: proxy signals for ocean chemistry, climate and tectonics. Chemical Geology 161, 127-163.

Bultynck, P., Dejonghe, L., 2002. Devonian lithostratigraphic units (Belgium). Geologica Belgica 4, 39-69.

Bultynck, P., Helsen, S., Hayduckiewich, J., 1998. Conodont succession and biofacies in upper Frasnian formations (Devonian) from the southern and central parts of the Dinant Synclinorium (Belgium) - (timing of facies shifting and correlation with late Frasnian events). Bulletin de l'Institut Royal des Sciences Naturelles de Belgique, Sciences de la Terre 68, 25-75.

Came, R.E., Eiler, J.M., Veizer, J., Azmy, K., Brand, U., Weidman, C.R., 2007. Coupling of surface temperatures and atmospheric carbon dioxide concentrations during the Palaeozoic Era. Nature 449, 198-201.

Chen, D., Tucker, M.E., Shen, Y., Yans, J., Préat, A., 2002. Carbon isotope excursions and sea-level change: implications for the Frasnian-Famennian biotic crisis. Journal of the Geological Society 159, 623-626.

Coen, M., 1977. La Klippe du Bois Niau. Bulletin de la Société Belge de Géologie 86, 41-44.

Coen, m., 1999. Formation de Barvaux. Memoirs of the Geological Survey of Belgium 44, 61-65.

Coen-Aubert, M., Lacroix, D., 1979. Le Frasnien dans la partie orientale du bord sud du Synclinorium de Namur. Annales de la Société Géologique de Belgique 101, 269-279.

Coleman, M.L., Walsh, J.N., Benmore, R.A., 1989. Determination of both chemical and stable isotope composition in milligram-size carbonate samples. Sedimentary Geology 65, 233-238.

da Silva, A.C., Boulvain, F., 2008. Carbon isotope lateral variability in a Middle Frasnian carbonate platform (Belgium): significance of facies, diagenesis and sea-level history. Palaeogeography, Palaeoclimatology, Palaeoecology 269, 189-204.

Denayer, J., Poty, E., 2010. Facies and palaeoecology of the upper member of the Aisemont Formation (Late Frasnian, S. Belgium): an unusual episode within the Late Frasnian crisis. Geologica Belgica 13, 197-212.
Elderfield, H., 1988. The oceanic chemistry of the rare-earth elements. Philosophical Transactions of the Royal Society of London 325, 105-126.

Godefroid, J., Helsen, S., 1998. The last Frasnian Atrypida (Brachiopoda) in southern Belgium. Acta Palaeontologica Polonica 43, 241-272.

Grossman, E.L., Zhang, C., Yancey, T.E., 1991. Stable isotope stratigraphy from brachiopods in Pennsylvanian (Upper Carboniferous) shales of Texas. Geological Society of America Bulletin 103, 953-965.

Immenhauser, I., Holmden, C., Patterson, W.P., 2008. Interpreting the carbon-isotope record of ancient shallow epiric seas: lessons from the Recent. Geological Association of Canada, Special Paper 48, 137-174.

Izokh, O.P., Izokh, N.G., Ponomarchuk, V.A., Semenova, D.V., 2009. Carbon and oxygen isotopes in the Frasnian-Famennian section of the Kuznetsk Basin (southern West Siberia). Russian Geology and Geophysics 50, 610-617.

Joachimski, M.M., Buggisch, W., 1993. Anoxic events in the late Frasnian-cause of the Frasnian-Famennian faunal crisis? Geology 21, 675-678.

Joachimski, M.M., Buggisch, W., 1996. The Upper Devonian reef crisis-insights from the carbon isotope record. Göttinger Arbeiten zur Geo-logie und Paläontologie, 2, pp. 365-377.

Joachimski, M.M., Buggisch, W., 2002. Conodont apatite $\delta \stackrel{18}{\mathrm{O}}$ signatures indicate climate cooling as a trigger of the Late Devonian mass extinction. Geology 30, 711-714.

Joachimski, M.M., van Geldern, R., Breisig, S., Buggisch, W., Day, J., 2004. Oxygen isotope evolution of biogenic calcite and apatite during the Middle and Late Devonian. International Journal of Earth Sciences 93, 542-553.

Lacroix, D., 1999. Formation d'Aisemont. Memoirs of the Geological Survey of Belgium 44, 92-95.

Lecompte, M., 1960. Compte rendu de la session extraordinaire de la Société géologique de Belgique et de la Société belge de Géologie, de Paléontologie et d'Hydrologie du 25 au 28 septembre 1959. Annales de la Société géologique de Belgique 83, 1-134.

Lecompte, M., 1970. Die Riffe im Devonder Ardennen und ihre Bildungsbedingungen. Geologica et Palaeontologica 4, 25-71.

Lee, J.H., Byrne, R.H., 1993. Complexation of trivalent rare earth elements (Ce, Eu, Gd, $\mathrm{Tb}, \mathrm{Yb})$ by carbonate ions. Geochimica et Cosmochimica Acta 57, 295-302.

Lowenstam, H.A., 1961. Mineralogy, $\stackrel{18}{\mathrm{O} /{ }^{16} \mathrm{O}}$ ratios, and strontium and magnesium contents of recent and fossil brachiopods and their bearing on the history of the ocean. Journal of Geology 69, 341-360.

Ma, X.-P., Wang, C.-Y., Racki, G., Racka, M., 2008. Facies and geochemistry across the Early-Middle Frasnian transition (Late Devonian) on South China carbonate shelf: comparison with the Polish reference succession. Palaeogeography, Palaeoclimatology, Palaeoecology 269, 130-151.

Maillieux, E., Demanet, F., 1929. L'échelle stratigraphique des terrains primaires de la Belgique. Bulletin de la Société belge de Géologie, de Paléontologie et d'Hydrologie 38, 124-131.

McLennan, S.M., 1989. Rare earth elements in sedimentary rocks: influence of provenance and sedimentary processes. In: Lipin, B.R., McKay, G.A. (Eds.), Geochemistry and Mineralogy of Rare Earth Elements: Mineral. Soc. Am. Rev. Miner., 21, pp. 169-200.

Mii, H.-S., Grossman, E.L., Yancey, T.E., 1999. Carboniferous isotope stratigraphies of North America: implications for Carboniferous paleoceanography and Mississippian glaciation. Geological Society of America Bulletin 111, 960-973.

Mottequin, B., 2005. Les brachiopodes de la transition Frasnien/Famennien dans le Bassin de Namur-Dinant (Belgique). Systématique - Paléoécologie - Biostratigraphie - Extinctions. PhD thesis, University of Liège.

Mottequin, B., 2008a. Late Middle to Late Frasnian Atrypida, Pentamerida, and Terebratulida (Brachiopoda) from the Namur-Dinant Basin (Belgium). Geobios 41, 493-513.

Mottequin, B., 2008b. New observations on Upper Devonian brachiopods from the Namur-Dinant Basin (Belgium). Geodiversitas 30, 455-537.

Mottequin, B., 2008c. Late middle Frasnian to early Famennian (Late Devonian) strophomenid, orthotetid and athyridid brachiopods from southern Belgium. Journal of Paleontology 82, 1052-1073.

Myers, K.J., Wignall, P.B., 1987. Understanding Jurassic organic-rich mudrocksnew concepts using gamma-ray spectrometry and palaeoecology: examples from the Kimmeridge Clay of Dorset and the Jet Rock of Yorkshire. In: Legget, J.K., Zuffa, G.G. (Eds.), Marine Clastic Sedimentology. Graham and Trotman, London, pp. 172-189.

Poty, E., Chevalier, E., 2007. Late Frasnian phillipsastreid biostromes in Belgium. Geological Society, London, Special Publications 275, 143-161.

Tsien, H.H., 1975. Introduction to the Devonian reef development in Belgium. Second International Symposium on fossil corals and reefs, Guidebook Excursion C (Nord de la France et Belgique). Belgian Geological Survey, Brussels, pp. 3-43.

van Geldern, R., Joachimski, M.M., Day, J., Jansen, U., Alvarez, F., Yolkin, E.A., Ma, X.P., 2006. Carbon, oxygen and strontium isotope records of Devonian brachiopod shell calcite. Palaeogeography, Palaeoclimatology, Palaeoecology 240, 47-67.

Veizer, J., Fritz, P., Jones, B., 1986. Geochemistry of brachiopods: oxygen and carbon isotopic records of Paleozoic oceans. Geochimica et Cosmochimica Acta 50, 1679-1696.

Veizer, J., Ala, D., Azmy, K., Bruckschen, P., Bruhn, F., Buhl, D., et al., 1999. ${ }^{8 z}$ Sr/ ${ }^{86}$ r, $\delta^{18}$ O and $\delta \mathrm{C}$ evolution of Phanerozoic seawater. Chemical Geology 161, 59-88.

Wadleigh, M.A., Veizer, J., 1992. ${ }^{18} \mathrm{O} /{ }^{16} \mathrm{O}$ and ${ }^{13} \mathrm{C} /{ }^{12} \mathrm{C}$ in Lower Paleozoic articulate brachiopods: implications for the isotopic composition of seawater. Geochimica et Cosmochimica Acta 56, 431-443. 
Webb, G.E., Kam er, B.S, 2000. Rare ear:h elenents ir. holocene reefal microbialites: a new shallow seawater proxy. Geochimica eCosr:10chimica Acta G4, i557-'-SGS.

Wenzel, B.. Joachinski, l'vl.:V'... 1!J!J6. Carbor. ar.d oxygen isotopic composition of Silurian brachiopods lGot!al'.d, Sweden;: paleocear:ographic implica:ions. Paleogeography, Paleoclimacology, Paleoecology 122, 143-166.

Wignall. P.B., Twi<cht:'tt, R.J., 19\%. fkPanfc anoxia anrl tht:' Pnd PNl'tian mass Pxtinction. Sdence 272, 1135--; 58.
Wigr.all, P.B.. Zonneveld, J.-P.. :-.iewlor., R.J., Amor. K, Sephlon, !vi.A.. Earlley, S., 2007. The end Triassic Bass exUl'.ctiol'. record ofV \illiston Lake. British Columbia. Palaeogeography, Palaeoclimatology, Palaeoecology 253, 385-406.

Y:Jdir:a, A.B.. Racki, G., Savage, N.M., Racka, M, :vlalkowski, K., 2002. The Frasnian-Fanennian evenls ir_a deep-shelf successior_, Subpolar Urals: biolic. rlPpnsf:fnnal, ard gPnchPmfcal rt:'cmds. Ac:a Palat:'m:tnlngfca Pnlnnica 47 (7.), 335--372. 